Cahiers $d u$ MONDE RUSSE

\section{Cahiers du monde russe}

Russie - Empire russe - Union soviétique et États indépendants

42/2-4 | 2001

La police politique en Union soviétique, 1918-1953

\title{
Gender and policing in Soviet West Ukraine,
}

1944-1948.

Jeffrey BURDS

\section{OpenEdition \\ Journals}

Édition électronique

URL : https://journals.openedition.org/monderusse/8454

DOI : $10.4000 /$ monderusse. 8454

ISSN : $1777-5388$

Éditeur

Éditions de l'EHESS

Édition imprimée

Date de publication : 1 avril 2001

Pagination : 279-320

ISBN : 2-7132-1398-3

ISSN : $1252-6576$

Référence électronique

Jeffrey BURDS, « Gender and policing in Soviet West Ukraine, 1944-1948. », Cahiers du monde russe [En ligne], 42/2-4 | 2001, mis en ligne le 01 janvier 2007, consulté le 02 septembre 2022. URL : http:// journals.openedition.org/monderusse/8454; DOI : https://doi.org/10.4000/monderusse.8454 
chercher : repérer : avancer

Cet article est disponible en ligne à l'adresse :

http://www.cairn.info/article.php?ID REVUE=CMR\&ID NUMPUBLIE=CMR 422\&ID ARTICLE=CMR 4220279

Gender and policing in Soviet West Ukraine, 1944-1948

par Jeffrey BURDS

Editions de I'EHESS | Cahiers du monde russe

2001/2-3-4 - Vol 42

ISSN 1252-6576 | ISBN 2713213983 | pages 279 à 320

Pour citer cet article :

-BURDS J., Gender and policing in Soviet West Ukraine, 1944-1948, Cahiers du monde russe 2001/2-3-4, Vol 42, p. 279-320.

Distribution électronique Cairn pour les Editions de l'EHESS.

(C) Editions de l'EHESS. Tous droits réservés pour tous pays.

La reproduction ou représentation de cet article, notamment par photocopie, n'est autorisée que dans les limites des conditions générales d'utilisation du site ou, le cas échéant, des conditions générales de la licence souscrite par votre établissement. Toute autre reproduction ou représentation, en tout ou partie, sous quelque forme et de quelque manière que ce soit, est interdite sauf accord préalable et écrit de l'éditeur, en dehors des cas prévus par la législation en vigueur en France. Il est précisé que son stockage dans une base de données est également interdit. 


\title{
GENDER AND POLICING IN SOVIET WEST UKRAINE, 1944-1948*
}

\author{
"War displays forms of male violence against women \\ that are usually blurred and kept hidden but implicit by \\ peacetime social structures." \\ Claudia Opitz, "From women in war to war against women."
}

\section{Prelude}

On 21 January 1947, working on information obtained through reliable informants, a special forces unit (spetsgruppa) of the Main Directorate for the Struggle Against Banditry (Glavnoe upravlenie po bor'be $s$ banditizmom - GUBB) of the Soviet Ministry of Internal Affairs (MVD) learned the location of the hideout of "Mykhailo," the chief of the dreaded Sluzhba Bezpeki (SB), or Ukrainian rebel underground intelligence service, and a member of the central command of the

\footnotetext{
* I would like to express my thanks to the Harry Frank Guggenheim Foundation, which has generously supported this research. I am grateful to the following archivists and scholars who provided assistance in Russian and Ukrainian research collections: S. V. Mironenko, V. A. Kozlov, and D. N. Nokhotovich in the State Archive of the Russian Federation in Moscow; K. M. Anderson, N. V. Murav'eva, and E. E. Kirillova at the Russian State Archive for Social and Political Research; V. I. Kutsynda and the late L. M. Minaeva of the State Archives of L'viv and Drohobych oblasti (Ukraine); Liuba and Oleh Kiselik of the Center for Ukrainian Studies (L'viv); Iu. I. Shapoval, N. V. Makovska, and I. L. Komarova at the Central State Archives of Public Organizations of Ukraine (Kyiv). Thanks are also due to John Armstrong, Chrystia Chomiak, Arch Getty, Christina Gilmartin, John-Paul Himka, Hiroaki Kuromiya, Norman Naimark, Natalie Nenadic, Douglas Northrop, Gabor Rittersporn, Roman Senkus, Patty Slotter, Andrei Sokolov, Terry Martin, and Lynne Viola.

Place names and transliterations correspond to the Library of Congress system for translations from Russian and Ukrainian. For the sake of consistency, all Ukrainian place names have been rendered in their Ukrainian equivalents.

1. Claudia Opitz, "Von Frauen im Krieg zum Krieg gegen Frauen: Krieg, Gewalt und Geschlechterbeziehungen aus Historischer Sicht," Homme, 3, 1 (1992): 31-44. Cf. Ruth Seifert: "War crimes against women have a symbolic meaning and must be analyzed within the symbolic contexts of the nation and the gender system." ("The second front: The logic of sexual violence in wars," Women's Studies International Forum, 19, 1-2 (1996): 35-43).
} 
Organization of Ukrainian Nationalists (OUN) and the Ukrainian Insurrection Army (UPA). ${ }^{2}$ The Soviets had hunted for Mykhailo as a priority target for apprehension or liquidation for more than five years, and they took every precaution to make sure he did not slip away. His hideout was located just two kilometers east of Zhukov village, in Berezhanskyi raion, Ternopil oblast'.

On the night of the 21st of January, a heavily armed Soviet unit surrounded Mykhailo's underground hideout, and ordered those inside to surrender. One of the men in the hideout responded with a volley of machine-gun fire, and was instantly cut down. In the ensuing minutes, and faced with insurmountable odds, Mykhailo, his wife "Vera" and his communications officer "Natalka" set fire to documents. Then, one by one, Mykhailo killed his wife and his messenger with shots to the head from his own revolver, then subsequently turned the gun on himself.

The four bodies were later identified from MVD "trophy photos" taken at the scene. Mykhailo was Mykola Arsenych-Berezovskyi. Born in 1910, and with a higher education, he joined the OUN in 1939, after he fled the Soviets by crossing over into German-occupied Poland. In 1940, as the Germans prepared to invade the Soviet Union, Mykhailo received advanced training in sabotage and diversion at a special espionage school for infiltration agents set up by the Germans in Krakow. After leaving the school, Mykhailo began working in the central command of Ukrainian rebel intelligence from 1940. Returning to Ukraine as an officer in a special sabotage unit attached to the German army in June 1941, Mykhailo was appointed commander-in-chief of the entire SB by the end of the first year of the war.

Mykhailo's wife Vera had been the chief of the women's unit in the L'viv city command of the OUN. Natalka had been a liaison officer for the central staff of the OUN. The face of the fourth - another man - had been destroyed by a grenade and was unrecognizable.

Despite Mykhailo's frantic efforts to destroy SB archives before his suicide, the successful Soviet seek-and-destroy operation recovered two knapsacks of documents from his dugout. These included valid Soviet passports with assorted aliases, party, MVD, militia, and Komsomol identification cards, lists of locals killed by the Soviets, and other documents. ${ }^{3}$ By far the most valuable document

2. The two key agencies of the Soviet secret police were the People's Commissariat of Internal Affairs (NKVD) and the People's Commissariat of State Security (NKGB). In March 1946 they were renamed the Ministry of Internal Affairs (MVD) and the Ministry of State Security (MGB). Until 21 January 1947, the spetsgruppy or special tasks units were subordinated to the NKVD/MVD's State Directorate for the Struggle Against Banditry (GUBB). Thereafter, they were transferred to the control of the MGB until the reorganization of the Soviet police system following Stalin's death in 1953.

3. See the original report in a coded telegram from the scene, dated 27 January 1947. Gosudarstvennyi Arkhiv Rossiiskoi Federatsii (GARF), f. R-9478 Glavnoe upravlenie po bor'be s banditizmom MVD SSSR (1938-1950 gg.) (GUBB MVD/NKVD SSSR), op. 1, d. 888, 11. 111112; and the top secret report from Soviet MVD S. Kruglov to Stalin, dated 29 January 1947. GARF, f. R-9401 Ministerstvo Vnutrennikh Del SSSR, 1934-1960 (MVD SSSR), op. 2, d. 168, 11. 145-146. This account is substantiated by versions published in the OUN's own histories. See Petro R. Sodol, Ukrains'ka Povstancha Armiia, 1943-1949. Dovidnyk (New York: Proloh, 19941995), 2 vols, I: 64 . In this diaspora account, Mykhailo is said to have died "a heroic death," while neither his wife nor his communications officer are even mentioned. 
recovered from Mykhailo's personal archive was an eight-page letter he had written to Roman Shukhevych, commander-in-chief of the Ukrainian Insurrection Army, just one week before Mykhailo's death. In that letter, Mykhailo perceptively appraised the status of the Ukrainian insurrection, and identified the chief threat to the movement to lie in Soviet agentura: "Secret informers - these are the most numerous and dangerous of denouncers. These 'moskity' (mosquitoes) infect the healthy body of our organization. From this form of agentura we have suffered our greatest losses." Mykhailo was certain that these secret informers were ubiquitous within the rebel movement: "If one considers that there are no less than five such informers in every village, their significance becomes clear."

Unknown to Mykhailo, the rebel leadership, or to scholars for the next fifty years was the fact that Mykhailo's whereabouts had been betrayed by a Soviet informant within his own inner circle: Natalka, the liaison officer, was a Soviet spy. ${ }^{5}$

\section{The Soviet recruitment of agent "Natalka"}

Natalka's story was all too typical. Her recruitment in June 1945 had been handled by the star and principal innovator of Soviet spetsgruppy tactics in West Ukraine, Major A. M. Sokolov, based in Ternopil oblast'. Sokolov was so good at his job transforming diehard anti-Soviet Ukrainian nationalists into members of his own force to destroy the rebel underground - that he had written the standard primer for Soviet MVD/MGB field officers on spetsgruppy tactics against anti-Soviet rebel groups. ${ }^{6}$

4. Arkhiv MVD SSSR, f. 488 Upravlenie vnutrennikh voisk MVD Ukrainskogo okruga, op. 1, d. 227, 11. 76-95.

5. Soviet police files are problematic sources. For a survey of special concerns, see Boris V. Anan'ich, "The historian and the source: The problems of reliability and ethics"; and Jeffrey Burds, "Ethnicity, memory, and violence: Reflections on special problems in Soviet and East European archives," forthcoming in a special issue of Archivum, "Archival politics in dissolving states," William Rosenberg and Nancy Bartlett, eds, 2002.

6. "Nastavlenie po ispol'zovaniiu voisk NKVD pro provedenii chekistko-voiskovykh operatsii," NKVD SSSR, top secret, 1944. From a third typescript copy preserved in Arkhiv SB (L'viv, Ukraine). According to his personnel file at GUBB, Major A. M. Sokolov, Chief of the Ukrainian MVD-GUBB in Ternopil oblast' in early 1946, was later that year transferred for special duty in Lithuania, "as a person having practical experience regarding the organization and work of the spetsgruppy" - the GUBB clandestine units that specialized in domestic black operations. Sokolov's specialty was disorganization. See GUBB chief A. A. Leont'ev's orders for Sokolov's temporary transfer to Lithuania, dated 26 March 1945. GARF, f. R-9478, op. 1, d. 527,1 . 14. On Sokolov's preeminent role leading Soviet spetsgruppy disguised as underground anti-Soviet partisans in the postwar suppression of anti-Soviet rebels in Lithuania, see: Juozas Daumantas [alias for Juozas Luksa], Fighters for freedom: Lithuanian partisans versus the USSR (1944-1947) (Toronto: The Lithuanian Canadian Committee for Human Rights, 1975), 2nd ed.: 81-82; and K. V. Tauras, Guerilla warfare on the amber coast (New York: Voyager Press, 1962): 78-80. Also see top secret communiqué from Deputy MVD V. Riasnoi to Lithuanian MVD Major-General Vartashunas in Vilnius, 29 June 1946. GARF, f. R9478, op. 1, d. 527, 1.27. 
As I have shown elsewhere, the Soviets effectively used agentura or informants' networks as a means to sow suspicion among anti-Soviet Ukrainian nationalist rebel groups in West Ukraine at the end of World War II. Agentura became a powerful tactical weapon utilized by the Soviets to provoke rebel terror as a means by which to drive a wedge between organized rebel forces and their support bases among local civilians. ${ }^{7}$ Here, I will focus my investigation on the Soviet use of agentura: how the Soviets detected the opportunities afforded by the rebels' shift to gender-based recruitment tactics, and how they eventually began to target ethnic Ukrainian women and girls as Soviet siksotki or "secret agents" to provoke cancerous terror reprisals from within the underground.

In this pursuit, we are fortunate because Major Sokolov left a detailed handwritten account of his successful turning of agent Natalka in a top secret report to Major-General A. P. Gorshkov, the chief of the First Department of the elite Soviet police unit, the Main Directorate for the Struggle Against Banditry (GUBB NKVD). ${ }^{8}$ Sokolov wrote in his candid summary report:

"At that time, the Berezhany [MVD] raion office had detained a [rebel] courier - 'Natalka' - who had confessed during interrogation that she was a liaison officer for the commander of the OUN in [Ternopil] oblast', 'Nestor.'

She [Natalka] had tried to escape from her place of detention - and had even shot with a pistol the militiaman who was guarding her. And it was evident from information received that her figure was interesting (figura byla interesnaia).

My assistant - Lieutenant-Colonel [A. I.] Matveev - and I went to Berezhany to take a look at her."10

Soldiers shared stories, and during her short time in Soviet captivity, Natalka had already earned herself the reputation of a "cantankerous filly" who would be a challenge to break. Evidently, Sokolov was lured by the challenge.

Self-confident after a series of successes, Sokolov took personal charge of Natalka's recruitment.

7. See Jeffrey Burds, "AGENTURA: Soviet informants' networks and the Ukrainian rebel underground in Galicia, 1944-1948," East European Politics and Societies, 11, 1 (Winter 1997): 89-130.

8. The extraordinary summary report was originally written in Sokolov's own hand, preserved in GARF, f. R-9478, op. 1, d. 487, 11. 175-199. Subsequently, the report was typed and resubmitted over Sokolov's name to Leont'ev, with a cover letter from Gorshkov successfully nominating Sokolov for a medal. See the typed and corrected report on GARF, f. R-9478, op. 1, d. $487,11.212-223$. The report is a summary of how Sokolov put together the spetsgruppa "Bystryi" in Ternopil oblast' in 1945.

9. "Nestor" was the alias for Ivan Shinayda, the UPA's oblast' commander in Ternopil. Nestor was not apprehended in this operation, but was subsequently killed by the Soviets in March 1946. For biographical information, see P. R. Sodol, op. cit., I: 132.

10. Sokolov deliberately used a double entendre here. Figura byla interesnaia would usually mean: "This was an interesting person." But here and throughout the account of Natalka's recruitment, Sokolov uses sexual connotations, and hence the dual meaning: "her figure was interesting" or "she had a good figure." 
"When we arrived in Berezhany, she was being interrogated by GUBB-NKVD Ukrainian SSR Lieutenant-Colonel Kaganovich. She gave her answers in such a way that made it impossible to exploit them operationally. It was clear she was lying about everything, and hiding something big.

I shared my opinion with Matveev, who agreed with me, and so we decided to take her to Chertkov. During her interrogation at Chertkov, she likewise essentially gave us nothing, so [my commanding officer Colonel A. A.] Saraev ordered me to take her into my spetsgruppa, take her back to Berezhany, and find some way of compelling her to tell us what she knew, and to exploit that information uncovered during her interrogation."

Sokolov's account does not reveal what happened in the intervening period. Whatever happened between Sokolov and Natalka for the few days before he chose to bring her back to Berezhany, she evidently returned convinced that she had fooled Sokolov into believing she was now a Soviet agent. The wily Sokolov knew otherwise, and time and again in his account, he seemed to recognize and respect the fact that threats, violence, and intimidation alone would never break Natalka. Her turning would require a major deception.

"On our return to Berezhany, I decided to act as if [I believed] she had been successfully recruited. And so I gave her her first assignment: to murder [her commanding officer in the rebel underground] 'Nestor.' I was confident that she would run, and had set a plan wherein during the time she was trying to escape us she would be captured by [one of my units operating] under the guise of the [rebel] SB, who would interrogate her as a siksot. One could do nothing else with her.

On the road to Berezhany, we made sure she did not see the entire unit. We treated her well. In Berezhany I formally recorded her recruitment, gave her the assignment to murder 'Nestor,' issued her a pistol (with the firing pin removed), and dispatched her to carry out the assignment."11

Natalka did her best to deceive Sokolov, playing the role of a successfully recruited Soviet siksot. Feigning compliance, she indicated that she often met with some rebel soldiers from Nestor's unit in a cottage in village Byshky. The rebel soldiers, she alleged, would lead her from there to Nestor's hideout in the woods. Sokolov played along, but unknown to Natalka, he ordered an NKVD unit to surround the village and make sure no one escaped.

"Just as I suspected, so it happened: Natalka went into the cottage for a few minutes, then exited through the rear door, and hid herself in the cornfield behind the cottage. My agent Horodetskyi saw everything, but let her sit a while

11. For the NKVD/NKGB, "formally recording a recruitment" was a highly ritualized procedure that included the requirement that new recruits sign written oaths of allegiance to Soviet power, and choose a special field alias, a new name for their work as Soviet agents. Psychologically, this process was designed to assist the recruit to adopt a new identity. Practically, it also put the recruit under the total control of Soviet police: if leaked, that information would bring an automatic death penalty to the signatory, as well as to his family and loved ones. 
in the corn. Then, as if by accident, [and masquerading as an SB officer] he detained her, found her pistol and immediately accused her of being a siksotka."

Natalka was evidently floored, and utterly duped by the ruse. She immediately imparted to the false SB chief that she was a liaison officer for the central staff of the OUN, and that she needed to see her commanding officer as soon as possible. Having missed the first two planned meetings with her associates, she had just one more fallback meeting before her contacts would assume she had been arrested, and would sever their contact altogether. The information she carried was of vital interest to the rebel underground, and she begged the SB chief to help her.

Continuing the meticulously planned and executed masquerade, Horodetskyi resisted, called Natalka a liar and provocateur desperate to save her own skin. Following standard SB procedure, Natalka was blindfolded and led to a hideout in Berezhany, where she was interrogated at length. More and more desperate, only then did Natalka pass the point of no return and become an unwitting accomplice of the NKVD: she confessed to know the location of a liaison point in village Avgustovka where she could connect with the leadership of the rebel unit Belyi.

That was all Sokolov needed to know. The well-hidden rebel hideout of Belyi unit was subsequently taken, most of its inhabitants captured alive. The rebel commander "Rynchak" was killed in the operation, but his deputy commander "Chad" was captured alive and broken. And step by step the operation to turn Natalka began to bear fruit. Interrogated by the Soviets, Chad revealed the location of a rebel hideout near village Rai where rebel commander Belyi was supposed to be quartered. Instead, his adjutant "Artem" was surrounded: Artem too resisted, setting fire to his archive, to a large cache of money, and to his hideout - even killing his own woman liaison officer "Legeta" before he was shot in the leg while attempting to escape. Artem was captured alive. ${ }^{12}$

By this time the rebel deputy commander Chad had been recruited into the NKVD spetsgruppa, and he and Sokolov worked together closely to exploit his intimate knowledge of local rebel units. Chad led the Soviets to "Chaban," former chief of the gendarmerie for the rebel Bystryi unit. Chaban was also recruited into the Soviet spetsgruppa, and his extensive knowledge about the identities and locations of local rebel cadres kept the Soviet secret police in Ternopil busy for an entire month of successful liquidation operations. Just one successful recruit had delivered a devastating blow to the SB in Ternopil.

12. Initially resistant to Soviet overtures, "Artem" - alias for Vasyl' Chizhevs'kyi - was eventually turned by the Soviets. Soon after, in April 1945, he became chief of communications between rebel units of the UPA under the leadership of Roman Shukhevych and their foreign base of operations in Munich, Germany. Traveling back and forth between Galicia and Munich, Artem was - according to diaspora sources - captured by the Soviet MGB on the Czechoslovak border with West Germany on 4 December 1945. In fact, as Sokolov's account suggests, Artem was probably turned into a Soviet double agent as early as April 1945; which means the 4 December "arrest" was probably just a regular debriefing by his Soviet controllers. In any case, Artem continued to work for the Soviets until summer 1947, when he was assassinated in Germany by the Ukrainian SB. For Artem's biographical information, see P. R. Sodol, op. cit., II: 108-109. 
From this point, we lose track of Natalka in declassified Soviet files for nearly eighteen months, until the operation to liquidate Mykhailo in which she herself was killed. Undoubtedly, Sokolov imparted to his unwitting recruit the consequences of her information, news that would have broken her psychologically: the rebel underground did not tolerate betrayal, and took no account of a traitor's motivations or circumstances. Natalka had but one choice: either to cooperate with Sokolov, or to die, and bring reprisals on her family and loved ones. Such was the impeccable and brutal logic of Soviet agentura operations.

\section{The gender question and the Ukrainian rebel underground}

One of the most notable features of the history of gender in the Ukrainian underground of the 1940s is the relative silence about women's contributions. Soviet operations files reveal a regular presence, even majority, of women in Ukrainian rebel operations. In contrast, Ukrainian nationalist and diaspora publications contain comparatively little concrete information regarding women's roles in the underground. It is remarkable that in a literature that has produced such a rich and voluminous hagiography of Ukrainian male heroes, there are so very few accounts of women warriors. In the most recent two-volume edition of nationalist biographies, for instance, Petro Sodols The Ukrainian Insurrection Army: A reference guide (published in 1995), there are 338 "heroes" (and traitors) named, but only 17 are women. Of those 17 women members of the UPA, less than a handful were noted to have died "heroic deaths" in the field of battle against the Polish, Soviet, or German enemy. And, without exception, these 17 women heroes were deemed heroic either because they were murdered, because they served prison sentences, or - most often - because of their contributions to ancillary branches of the movement: to culture, child care, or education. In almost every case, ethnic Ukrainian women considered worth remembering for their contributions to the underground were wives, siblings, or offspring of male heroes. Equally telling is The Ternopil area: A list of heroes of the Ukrainian revolution fallen in the struggle with the Russian Bolshevik occupying power, 13.3.1944-31.12.1948, originally published in typescript in September 1949. The memorial book identifies 718 "fallen heroes," of whom only 18 were women. ${ }^{13}$

In a rare example where the heroic roles of Ukrainian women rebels have been discussed in detail, Marta N. (the writer's alias for UPA hero Halina Savits'kaHoloiad) upheld the Soviet observations that Ukrainian women proved to be just as courageous and steadfast in the field of battle as men. "A woman [in the Ukrainian underground]," she wrote in the late 1940s, "would always heroically maintain herself during Bolshevik or Polish interrogations, betraying neither secrets, nor

13. Reprinted in a corrected edition, Ie. Shtendera and P. Potichnyj, eds, Ternopil'shchyna. Spysok upavshykh heroiv ukrains' koi revoliutsii v borot' bi z moskovos' ko-bil 'shovyts' kim okupantom za chas vid 13.3.1944 r. do 31.12.1948 r. (Toronto: Litopys UPA, 1985). 
neighbors, determined sooner to face torment and death."14 Similarly, Soviet and German intelligence and counter-intelligence operatives consistently observed that, under interrogation, "female agents usually stuck more obstinately to their stories than did male agents. Logical arguments brought forward by the interrogating officer who tried to explain that the stories told by female agents could never be true, did not affect them to the same extent that they would have affected male agents." 15 Women were, it was generally believed among interrogators, harder to break with logical arguments, or the threat of force. Instead, women and children agents were more easily recruited either with blackmail or threats of reprisals against their families, or with a promise of enticements. ${ }^{16}$

We are left then with this conundrum: why, if in most Soviet accounts Ukrainian women played such a notable role in the Ukrainian liberation movement after the war, has so little been written on women's contributions? Why do we know so little about the women who belonged, and especially about their contributions beyond the ancillary roles in provisions, communications, and medical aid?

The challenge of ferreting out women's roles in West Ukrainian rebel operations goes far beyond merely chronicling women's substantial contributions. It also involves coming to terms with the haunting silence that has marked the intervening period.

14. Marta N., "Zhinka v Ukrains'komu vyzvol'nomu Rusi (Z vlasnykh sposterezhen')," in Ukrains 'ka Postans'ka Armiia: Zbirka dokumentiv za 1942-1950 rr. (Munich, 1957), Ch. 1: 90.

15. D. Karov, Interrogation methods used by German counterintelligence in Kharkov, Russia, 1941-1943 (Historical Division of the U.S. Army Europe, Foreign Military Studies Branch, 1953): 14. On men versus women agents in Ukraine, see pp. 12-13. Declassified by the U.S. Department of Defense on 31 October 1997. MS\# P-138.

16. Cf. the 20-page, closely reasoned analysis of Soviet secret police methods in West Ukraine entitled, "Agentura NKVD-NKGB v deistvii," produced by the Ukrainian rebel SB. GARF, f. R-9478, op. 1, d. 643,11. 13-34.

The only full-length West Ukrainian women's memoirs fail to discuss women's contributions on their own terms, but instead discuss memories of heroic men. For the most recent example, see Mariya Savchyn, Tysiacha dorih (spohady) (Toronto-L'viv: Litopys UPA, 1995) (Litopys UPA, Vol. 28). Similarly, of 25 autobiographies of women members of the Ukrainian underground who survived the 1940s that appear in Litopys niskorenoi Ukrainy: Dokumenty, materialy, spohady, Vol. 1 (L'viv: Prosvita, 1993), only one discusses women's contributions in detail. The overwhelming majority are victimologies chronicling the writer's hardship at the hands of Soviet authorities.

The other famous example of women's service to Ukrainian nationalism is likewise founded on the image of women as victims: during an inmate uprising in the Soviet forced labor camp at Kengir in 1953, more than 150 Ukrainian women and girls demonstrating in a peaceful march were crushed to death by Soviet tanks deployed to suppress the "riot." This case is often referred to in Ukrainian and diaspora texts to demonstrate the courage of Ukrainian women. 


\section{Women in West Ukraine}

"In war women have to do things they wouldn't dream about in peacetime. We all have to survive."

Woman refugee from West Ukraine, June 1945. ${ }^{17}$

NKVD operations reports, informants' files, and documents seized from the Ukrainian underground during the wartime and postwar periods reveal that there was a dramatically increased role of women in the anti-Soviet Ukrainian rebel underground in 1944-1945. Upon reflection, that observation seems reasonable. Ethnic Ukrainian men in West Ukraine between 1939-1950 had a one-in-three chance of dying during the era - either from violent disputes with ethnic Poles, the mass arrests and mass executions that marked the Soviet occupation of 1939-1941, followed immediately by the period of Nazi occupation from June 1941 to JulyAugust 1944. Young men fit for work also stood a good chance of deportation - to Siberian forced labor under the Soviets, or as Ostarbeiter under the Nazis. By autumn 1944, with the return of Soviet forces to the region, any Ukrainian male fourteen years or older was likely to be arrested, shot, or forced into Red Army or NKVD/NKGB service. Most West Ukrainian men aged 14-45 were as a result driven to forests or into underground hideouts, literally tombs underground where they waited for the end of hostilities. Friendly cadre or enemy other, the anti-Soviet warrior's gender was - in the Soviet view - distinctly male. ${ }^{18}$

At the height of the Soviet battle to re-occupy West Ukraine by driving out the Germans, a Ukrainian commander of a rebel unit based in Rava-Rus'ka raion on Poland's southeastern border, wrote in an extended report dated 21 August 1944:

"The Jew-Communist-Bolsheviks treat us [Ukrainians] like enemies. Not a single young [Ukrainian] man can even be seen by the Bolsheviks [without being detained, beaten, shot, or taken away]. The NKVD is conducting arrests with the assistance of secret agents (siksoty) and terror. In this way on 13.8.44 in village Lavrikiv nine people were arrested with the help of two informants - one of them, a Belorussian who had been here since 1941, and the other a fool from our own headquarters, who gave away and ruined our whole network. [The Soviets] surround villages, then detain anyone they can find. They so harshly taunt [villagers] that in the end [the Soviets] manage to find out everything they know: who was the officer-in-charge of the local band, where he is hiding, where are all the men. The bolsheviks used this method in Bilka Masovitska. On 16.8.44 they surrounded almost 200 people in the village, but arrested only the 50 men, and beat them very badly. They took 10 men away with them, and left 2 very seriously

17. Quoted in Waldemar Lotnik, Nine lives: Ethnic conflict in the Polish-Ukrainian borderlands (London: Serif, 1999): 191.

18. For a parallel case, see the perceptive reading of Lynne Viola, "WWe let the women do the talking': Bab'i bunty and the anatomy of peasant revolt," in id., Peasant rebels under Stalin: Collectivization and the culture of peasant resistance (New York: Oxford University Press, 1996): 181-204. Viola explains how comparatively lenient Soviet treatment of women led peasants to develop distinctly feminine forms of popular revolt, where women often led the expression of dissatisfaction, while men stood back. 
beaten. Some others were freed that same day, but the remaining 25 men were held until 21.8.44. In the same way on 18.8.44 [the Bolsheviks] surrounded village Lypna, detained all the men in the village and took them away with them, burned down three homes, shot one, and then left for Rava-Rus'ka."

It had gotten to the point, he wrote, that "whenever [men] catch sight of even one [Soviet] soldier they run away from their homes. At night they [the local men] don't sleep."19 And elsewhere: "In village Lisets [in Stanyslaviv oblast' in early August 1944] there was a recruitment levy that took away many men. The old men were released," while the rest were mobilized into the Red Army. ${ }^{20}$

The initial impact of the Soviet re-occupation of the western borderlands drove local men away from their villages. This observation was confirmed in numerous eyewitness reports. A doctor in eastern Poland, Zygmunt Klukowski in Szczebrzeszyn, left a description of the same pattern of gender-specific targeting by Soviet occupation forces in his diary entry for 10 October 1944: "Late in the evening on Sunday, Soviet troops encircled the village of Maszow. Going from house to house, they arrested approximately three hundred men, all of draft age, and transported them to the military barracks in Zamosc. It seems that this is the new way of forcing enlistment."21 In a March 1945 letter to her relatives, ethnic Ukrainian woman Z. F. Shevchuk wrote from her village in Drohobych oblast': "Spring here will be difficult. The Germans carried off all our horses and wagons, while the Soviets [have taken all the] men up to age forty-five into the army. Only a few [of the men] remain, [who] work in the forests [cutting wood]." 22 In a similar vein, another peasant woman from Drohobych, M. S. Vasiurko, wrote to her husband on 4 April 1945: "It's very warm here now, the weather only knows how to be spring. But this comes to nothing since we have no horses in the village, and likewise no men. Only women and a few old men remain in the village." 23

In the early Soviet occupation of West Ukraine in 1944, violence was perpetrated and repression was applied in a gender-specific way. Initially, Ukrainian men bore the brunt of the Soviet onslaught, while women - though

19. Report of the UPA company commander Erema dated 21 August 1944, found on the corpse of a rebel in Orlik company following a Soviet firefight on 24 August. The subsequent translation was forwarded by Lt.-Col. Tarasenko, deputy commander of the 5th Department of the Ukrainian NKVD. Derzhavnyi Arkhiv L'vivskoi Oblasti (DALO), f. 3 L'vivskyi obkom Kompartyi Ukrainy, op. 1, d. 70,11. 56-56 ob.

20. See the report for 15 August 1944 from Lisets raion rebel commander Kochevik to OUN headquarters, subsequently seized by the NKVD. Rossiiskii Gosudarstvennyi Arkhiv Sotsial'noPoliticheskoi Istorii (RGASPI), f. 17 Tsentral’nyi Komitet VKP(b), op. 125, d. 336, 1. 181.

21. Zygmunt Klukowski, Red shadow: A physician's memoir of the Soviet occupation of eastern Poland, 1944-1956 (Jefferson: McFarland \& Co., 1997): 24.

22. Letter of Ukrainian woman Z. F. Shevchuk in village Dovhe, Medenicheskyi raion, Drohobych oblast', to relatives in Kirovograd oblast', dated 20 March 1945. Interdicted and copied by military censors. DALO, f. 5001 Drohobychskyi obkom Kompartyi Ukrainy, op. 6, d. $46,11.96-96 \mathrm{ob}$

23. Letter of Ukrainian woman M. S. Vasiurko in Lyshnia village, Drohobych raion and oblast', to her husband, dated 4 April 1945. Interdicted and copied by military censors. DALO, f. 5001, op. 6, d. 46,1.97. 
victimized directly and indirectly - were (comparatively speaking) far more free to move around and go about their lives. Under the circumstances, and with no other choice, the Ukrainian nationalist underground relied increasingly on women and girls to perform tasks vital for the rebel movement.

This had not always been the case. John A. Armstrong has upheld the traditional impression that women were largely ignored in the ranks of the Ukrainian rebel underground before 1944. "In general, nationalist observers agree that the [Ukrainian] women were less politically active than the men. While there is too little evidence to warrant a firm conclusion on this score, it is just possible that the [Ukrainian] nationalist movements neglected a useful source of support, which was certainly tapped by the Communist underground."24

But necessity is the mother of invention, and in West Ukraine, this translated into a Ukrainian rebel policy that increasingly targeted women and girls as recruits into vital services for the rebel underground. The architect of this fundamental shift of tactics of the OUN and the UPA from a focus on male to female recruitment was Hryhorii Pryshliak (alias: "Mikushka") - in spring 1944, chief of the Sluzhba Bezpeki (SB) or rebel secret police in West Ukraine. ${ }^{25}$ The transcript of an NKVD interrogation of L'viv city SB chief Iosif Pan'kiv, captured by the Soviets on 28 October 1944, is quite specific about the new gender-based tactics of the Ukrainian underground on the eve of the Soviet return to West Ukrainian zones: "Working on the basis of an evaluation that men, particularly members of the SB, would with the arrival of the Red Army be seriously hampered operating as 'legals' in L'viv, MIKUSHKA decided to reorient [our tactics] towards the utilization of women for work in the SB." ${ }^{26}$ Subsequently, Pan'kiv was ordered to dismantle existing malebased networks, who were reorganized into military units mobilized for the partisan war against the Soviets. In their place, Pan'kiv recruited and trained women agents exclusively. As he prepared to leave L'viv himself, Pan'kiv's own 23-year-old sister Yulia (alias: "Ul'iana") was appointed SB chief for L'viv city. ${ }^{27}$

The call for more women in the ranks of the underground was soon taken up by the supreme command of the Ukrainian nationalist rebel leadership. Initially, mass recruitment began to attract more women into ancillary roles: for instance, there

24. John A. Armstrong, Ukrainian nationalism, 1939-1945. Third rev. ed. (Englewood: Ukrainian Academic Press, 1990): 187-188. On gender and Soviet partisans, see the groundbreaking discussion in Kenneth D. Slepyan, “'The people's avengers': Soviet partisans, Stalinist society and the politics of resistance, 1941-1944," Ph.D. Diss., University of Michigan, 1994, 250-265.

25. One of these new recruits was Mariya Savchyn (alias: Marichka), who has left an extensive memoir of her recruitment and subsequent service. See Mariya Savchyn, Tysiacha dorih (spohady), op. cit.

26. GARF, f. R-9478, op. 1, d. 135,1. 193.

27. Evidently, "Ul'iana" was herself turned and became a Soviet agent in June 1945. Though her agent files were removed to central archives of the Committee of State Security (KGB), her agent folder still remains, along with an informational note regarding her recruitment. The report reveals she was a high-priority agent run directly by T. A. Strokach, People's Commissar of Internal Affairs (NKVD) in Ukraine. See the folder and Strokach's report (dated 13 June 1945) in GARF, f. R-9478, op. 1, d. 487, 11. 75-76: "Dublikat lichnogo dela agenta UL'IANA." 
were instructions in July 1944 to increase the number of women in economic work. ${ }^{28}$ A rebel communiqué dated 14 August 1944 expanded the role of women in underground communications: "As soon as possible organize a communications network with sub-raion OUN units. Each communications link should be composed of four girls: one from the raion, and three from the sub-raiony." ${ }^{29}$ On 11 August and again in early October 1944 there were explicit instructions to expand zhinochi sitky - rebel "women's networks." ${ }^{30}$ These expanded networks were to become the recruiting grounds for reliable women to perform more clandestine work: women in communications, liaison work for underground transport along clandestine routes, espionage, and attached to specific units for medical care, provisions support, and even military and so-called "black" or "wet" operations. Rebel instructions from October 1944 reflected these more varied roles for women: "Under various pretexts send some of the [rebel] cadres - especially women - to the towns and [infiltrate them] among the [Soviet] workers." 31 Other instructions in October 1944 required Ukrainian women to work in the UChKh - the Ukrainian Red Cross.$^{32}$ After rudimentary training, beginning in late 1944, additional women agents of the Ukrainian rebel underground were regularly sent into eastern Ukraine for clandestine operations. ${ }^{33}$ Soon, it became standard operating procedure that Ukrainian "women are just as obligated to serve underground as men. [...] All women in the underground should carry pistols and, depending on availability, other weapons." ${ }^{34}$ By July 1945 Soviet NKVD units were regularly reporting evidence of armed rebel units made up predominantly or exclusively of young Ukrainian women..$^{35}$

28. Secret rebel "temporary instructions" on the arrival of the Red Army in West Ukraine, dated 7 July 1944. GARF, f. R-9478, op. 1, d. 126, 1.234

29. RGASPI, f. 17, op. 125, d. 336, 1. 48.

30. GARF, f. R-9478, op. 1, d. 126, 11. 226-228 ob.; 11. 315-315 ob.

31. Instructions from the OUN-UPA's central headquarters, dated 10 October 1944, as preserved in Stalin's MVD "Special Files." The top secret report of Beriia to Stalin was dated 6 January 1945. GARF, f. R-9401, op. 2, d. 92,1. 55. There are indications that this "feminization of the underground" was common in all areas that fell under Soviet control. See the numerous references to women in Z. Klukowski, op. cit.: passim; eg., p. 41: "It is possible to [maintain] contact $[\ldots]$ only through women messengers."

32. GARF, f. R-9478, op. 1, d. 126, 11. 316-317 ob.

33. GARF, f. R-9478, op. 1, d. 292,1. 15.

34. DALO,f. 5001, op. 7, d. 220,1. 143.

35. See, for instance, the handwritten field report to the chief of the Shumskyi raion NKVD Capt. Tresko from operations commander in Shumskyi raion, NKVD officer Iakovlev. Iakovlev described an UPA raiding unit of ten women armed with tommy guns and dressed in military clothing that sometimes masqueraded as a Soviet partisan unit. GARF, f. R-9478, op. 1, d. 487, 11. 203-203 ob. 


\section{The feminization of the Ukrainian underground}

"Woman, when intent on turpitude, is capable of sounding lower depths than the vilest of the male species." Hamil Grant, Spies and secret service (1915). ${ }^{36}$

Even before the Soviet "liberation" of West Ukraine by the end of July-August 1944, the marked shift in rebel tactics to utilize women warriors was noted favorably in German military intelligence reports. In a top secret memorandum, General-Major Brigadeführer Brenner wrote in mid-1944 to SSObergruppenführer General Hans Prützmann - the highest ranking German SS officer in Ukraine and the architect of the so-called "Prützmann Bureau," Germany's stay-behind or "werewolf" networks - that "The UPA has halted all attacks on units of the German army. The UPA systematically sends agents (razvedchiki), mainly young women, into enemy-occupied territory, and the results of the intelligence are communicated to Department 1c of the [German] Army Group" on the southern Front. ${ }^{37}$ This report was captured by the Soviets and became part of the Soviet NKVD's permanent "special file" on German wartime and postwar intelligence operations in West Ukraine..$^{38}$

The distinct gender shift in Ukrainian rebel tactics had almost immediately become apparent to NKVD field units operating in West Ukraine. In a top secret

36. As cited in Julie Wheelwright, The fatal lover: Mata Hari and the myth of women in espionage (London: Collins \& Brown, 1992): 1. On images of women in espionage, see the provocative work of Christine Bold, "Under the very skirts of Britannia: Re-reading women in the James Bond novels," Queen's Quarterly (Summer 1993): 311-328; and Julie Wheelwright, "Poisoned honey: The myth of women in espionage," Ibid.: 291-310. For a summary of women as targets of espionage recruitment, replacing the traditional "honey trap" with a modern "Romeo spy," see the autobiography of the chief of foreign security operations of the East German Stasi, Markus Wolf, "Spying for love," Man without a face: The autobiography of Communism's greatest spymaster (New York: Random House, 1997): 123-150.

37. GARF, f. R-9401, op. 1, d. 4152, 1. 340. On "Prützmann Bureau," see Perry Biddiscombe, Werewolf! The history of the national socialist guerrilla Movement, 1944-1946 (Toronto: University of Toronto Press, 1998).

In contrast, the Germans themselves evidently avoided using women agents in the East: "Female Agents: It was feared that a woman who was open to German suggestions could too easily be influenced again in other ways. Also, troop discipline was impaired when women were employed. Therefore, F[ront]A[uf]K[laerung] III used women agents only in special cases where no other solution could be found." The FAKs were responsible for front intelligence and counter-intelligence for the Abwehr. "German methods of combating the Soviet intelligence services," 3 May 1946, NARA RG 319 Records of the Army Staff, Records of the Office of the Assistant Chief of Staff, G-2, Intelligence. Records of the Investigative Records Repository. Security Classified Intelligence and Investigative Dossiers, 1939-76, NND921046 Heinrich Schmalschlaeger, IRR Box 11, Folders 1-2, 5-6.

German tactics had changed by the end of the war. "Among the trainees [for Werewolf detachments] were women and large numbers of Hitler Jugend." NARA, RG319 Records of the Army Staff, Records of the Office of the Assistant Chief of Staff, G-2, Intelligence, Records of the Investigative Records Repository. Security Classified Intelligence and Investigative Dossiers, 1939-76. U.S. Army Interrogation of Josef L. Roosen, 29 May 1945. Extract, 3.

38. On Western intelligence operations in West Ukraine during and after the war, see Jeffrey Burds, The early Cold War in Soviet West Ukraine, 1944-1948 (Pittsburgh: University of Pittsburgh, 2001) (Carl Beck Papers in Russian and East European Studies, $N^{\circ} 1505$ ) . 
memorandum dated 11 November 1944, NKVD Major in Soviet State Security V.A.Chugunov summarized information gleaned from interrogations of key personnel in the Ukrainian underground. His report spearheaded the growing Soviet awareness of a shift in rebel tactics that utilized Ukrainian women and girls more extensively than before:

"Following the expulsion of the German occupation from the western oblasti of Ukraine and the conducting of a mobilization of the male population into the Red Army, by order of the regional command of the OUN there were created village, sub-raion, raion, territorial (okrug), and oblast ' OUN command centers from among [local] women, who have the following departments (referentury): economic, communications, and reconnaissance.

At the present time the women's Economic Department plays the principal role in gathering provisions and other items needed by the UPA, since they can usually go about their economic activity more or less without suspicion. All collected provisions and items are then transferred to rebel control.

The primary task of women's reconnaissance (razvedka) is the collection of information about the movements of Red Army units, and about the departure from raion centers of NKVD personnel for operations. An officer-in-charge (stanichnaia) [is appointed from among local] women [who] each day assigns each of several female agents (razvedchitsy) to specific tasks. Every female agent is required to report back to a local command center three times a day (morning, afternoon, and evening) to find out what is new, and [to indicate] whether there are [Soviet] troops there [in her sector], and to inform the [female] officer-in-charge in the neighboring village regarding the situation in the village from where she came. This information is verified [each day directly by the female officer-in-charge] in a personal meeting with each female agent. Each day information is centralized with the local female officer-in-charge, who must make the decision whether to warn the rebels or to conceal illegals [hiding out nearby].

Women liaison [officers] (sviaznye) operate constantly and must maintain strict clandestinity. The liaison in one village knows the identity of only one liaison in a neighboring village, the one with whom she must maintain contact. [Rebel] correspondence moves from village to village along this relay network (estafetnaia sviaz), as do various orders, pamphlets, and nationalist literature. These same female liaison [officers] also serve as commanders of various messengers (posyl'nye), who follow the organization's affairs and keep tabs on the movements of OUN members." 39

Local women and children were commonly responsible for sounding the alarm to warn rebels illegally hiding out in or near their village. Since the traditional cry of "Kloptsi, vorog blyz'ko!" (Men, the enemy is near!) increasingly brought reprisals, the new cries by the end of 1944 were designed to protect the speaker from Soviet retaliation: "Bandits!”, “They're robbing us!”, or "They're killing us!"

39. Top secret communiqué of deputy chief of the Sixth Department of OBB NKVD SSSR, MGB Major Chugunov, 11 November 1944. GARF, f. R-9478, op. 1, d. 381, 11. 164-168. The report is based on a summary from interrogations of captured OUN-UPA personnel conducted in October 1944: D’iachishyn and Mykhailo Gachkevych. For biographical information, see P. R. Sodol, op. cit., II: 21 . 
Of course, gathering intelligence is not the same as developing successful tactics to combat the problem. In this case, the growing reliance of rebel forces on women and children was reflected in Soviet files more and more often throughout late 1944 and early 1945, as Soviet personnel scrambled to come up with a solution. In a top secret report dated 6 October 1944, the commander of the NKVD border patrol on the Ukrainian front observed the sticky problem of Ukrainian women and children spies who, he argued, were seriously undermining the effectiveness of Soviet operations:

"Many children aged 12-15 and women have worked and continue to work as active informants and messengers between bands and underground organizations of the OUN and UPA. They also organize the delivery of provisions for the bands and warn them about the appearance of [Soviet] border patrol units in their populated areas and about the latter's possible military operations against them. This corresponds with the instructions of OUN Center, which ordered [local commanders] to utilize [more] women for underground work - mainly for center-periphery communications." 40

The feeling that Soviet occupation forces were not doing enough to combat the specific challenges associated with women and children warriors appeared with rather alarming ubiquity in reports flowing out of West Ukraine. As the Zholkevskyi raion secretary Bychkov observed in a tête-à-tête with Ukrainian General Secretary Nikita Khrushchev in January 1945: the Ukrainian underground “has a large women's organization - the so-called women's network (zhinocha sitka). [...] [Women] are their main force - in communications (signalizatsiia), provisioning, and so on. I have met them. Yet we arrest very few women." Bychkov added sinisterly in a direct personal appeal to Khrushchev: "We have got to do something more about these women!"41

Not a single woman appeared among rebels killed or captured in the regular NKVD reports to Stalin regarding the struggle against the resistance in West Ukraine until February 1945. ${ }^{42}$ From that time on, women appeared more and more frequently in those summary reports of rebel casualties, reflecting the increased

40. From a top secret report of the commander of the NKVD border patrol on the Ukrainian front to Grushetskii, 6 October 1944. DALO, f. 3, op. 1, d. 70,1. 5 ob.

41. From the stenographic report of Khrushchev's meeting with leaders of the Soviet drive to pacify West Ukraine, 10 January 1945. DALO, f. 3, op. 1, d. 191,1.51.

42. This is based on a review of periodic reports to Stalin from the NKVD, preserved in the State Archive of the Russian Federation in Moscow, indexed in V. A. Kozlov and S.V. Mironenko, eds, Osobye papki I. V. Stalina (Moscow: Blagovest, 1994). The first Ukrainian woman spy to make it into reports to Stalin was Dr. Mariia Kotsiuba, a.k.a "Marta," detained in Stanyslaviv in February 1945. "Marta" was the daughter of a famous Ukrainian-Galician general from World War I, M. Tarnavskyi. See GARF, f. R-9401, op. 2, d. 93, 11. 54-62, top secret report dated 12 February (11. 55-56). 
proportion of suspected rebel women killed by Soviet forces in local reports. ${ }^{43}$ Although there are no gender breakdowns in aggregate numbers of casualties reported by the Soviets, it is possible to reconstruct the growing proportion of women as victims of Soviet violence through specific reports.

By March 1945, the ranks of the OUN-UPA had shifted from a relatively low reliance on women to an absolute dependence on women and girls in virtually every sector of underground activity. To take one example: from 20 February to $24 \mathrm{March}$ 1945, the regional organs of the NKVD and NKGB arrested 115 members of the OUN underground in Lopatynskyi raion (outside L'viv). Of these, 25 had carried on underground infiltration work for the OUN in the raion capital, passing information back to military units in the field. The majority of these rebel secret agents were women. ${ }^{44}$

Such a rising proportion did not go unnoticed by local Soviet cadres responsible for suppressing rebel activities. For instance, Borgunov, the party secretary from Strumilovskyi raion (also near L'viv), identified women as the chief enemy to Soviet power off the battlefield: "We have an enormous number of [Ukrainian rebel] women's networks (zhenskie setki, 'zhinocha sitka'). From the data it appears that in villages with, say, 1,000 people, there are 50-60 members of the OUN, and a considerable proportion of them are women. In some villages, they direct the [underground] work. Women's networks are not [as a rule] military units, but rather form the organizational, ancillary force of [rebel] bandits, with whom," Borgunov concluded ominously, "we must reckon, if not now then later."45

\section{"The sins of their fathers": The Soviet drive against insurgent families}

The unprecedented growth in numbers of Ukrainian women in the underground movement in 1944-1945 was more than just a matter of shifting rebel needs. The induction of increasing proportions of Ukrainian women into the rebel underground corresponded with a general political awakening of West Ukrainian women under a brutal Soviet occupation. Women were drawn into rebel support for a variety of reasons, but here as elsewhere a Soviet policy that failed to distinguish between civilians and organized rebels powerfully encouraged Ukrainian women's greater

43. For a depiction of the "heroic" aspects of women's contributions to the Ukrainian anti-Soviet underground resistance, see Marta N. [Halina Savits'ka-Holoiad], "Zhinka v Ukrains'komu vyzvol'nomu Rusi (Z vlasnykh sposterezhen'),' in S. F. Khmel', Ukrainska partyzanka: z kraiovykh materiialiv (London: Vyd. Zakord. Orhanizatsii ukr. natsionalistiv, 1959): 88-102.

Marta N. also offers numerous cases of Ukrainian women tortured for information about underground rebels. More recently, see twenty-five autobiographical sketches by women in the Ukrainian underground, published in Litopys niskorenoi Ukrainy, op. cit., I: 424-640; and fifteen biographies of women rebels in P. R. Sodol, op. cit., I: 70-73, 79, 83-84, 104-105, $116-$ 117, II: $10,20,26-27,35-36,44-45,81$.

44. From the report of the Secretary of the Lopatinskyi raikom Kostenko, DALO, f. 3, op. 1, d. 195, 1. 115.

45. DALO, f. 3, op. 1, d. 195, 1. 125. For similar data, see GARF, f. R-9478, op. 1, d 126, 11. 201-202. Here, among 300 members of an OUN-UPA band, 80 were women. 
participation in the anti-Soviet insurgency. The main problem was that women and family members were implicated and punished for the activities of their menfolk. As a Ukrainian rebel officer noted in an August 1944 report: "The Bolsheviks, not understanding what they themselves are doing, either drive people into hiding or arrest them. We must take this into consideration since in [Soviet abuses] lie both our strength and our hope."46

Punishing family members in insurgent areas was a vital and intrinsic part of Soviet police methods. As early as January 1945, the Soviets were keenly aware of distinct gaps in their methods. At a conference of raion chiefs and NKVD-NKGB officers in L'viv oblast', these principal agents of the Soviet pacification were openly critical of the failure to do more about rebel families. "In our work there is one mistake," argued the commanding officer of the 88th NKVD Border patrol. "We kill rebels, we see the rebel lying dead, but each [dead] rebel leaves behind a wife, a brother, a sister, and so on" - family members whose shared sense of victimization would generate incalculable future resistance. When, he asked, will Soviet forces begin to punish families? ${ }^{47}$

Among Soviet officials in West Ukraine, there was a dawning recognition that it was not enough to remove the active rebels alone: rather, the cancer of opposition had to be torn out by the roots - by harassing, arresting, imprisoning, torturing, and deporting family members as well. In a highly charged exchange with Khrushchev in a February 1946 meeting of raion and oblast' party, NKGB and NKVD chiefs plus battalion commanders in West Ukraine, Drohobych obkom secretary Oleksenko made a direct appeal to Khrushchev himself: "I beg you, Nikita Sergeevich. Give us the echelons so that we can deport the families of the rebels. This has great significance and will help us to achieve [our goal]. We are ready to conduct mass deportations. [...]"48

Within weeks, Khrushchev gave his formal approval for expanded operations, and the mass deportations of rebel families from West Ukraine expanded dramatically. As of June 1945, 10,139 Ukrainian families (26,093 persons) of suspected anti-Soviet rebels had already been deported to Siberia. ${ }^{49}$ Initially, "Many believed that we [Soviet officials] would not actually deport them, but were only trying to scare them." ${ }^{50}$ The bitter truth came as the pace of deportations

46. Report of the UPA company commander Erema dated 21 August 1944, found on the corpse of a rebel in Orlik company following a Soviet firefight on 24 August. DALO, f. 3, op. 1, d. 70, 1. 56. 47. DALO,f. 3, op. 1, d. 191,1.46. A report from Drohobych dated 27 December 1945 suggests substantial popular support for this notion. DALO, f. 5001, op. 6, d. 53, 11. 233-234.

48. Extract from "Stenogramma soveshchaniia sekretarei Obkomov KP(b)U, nach[al'nikov] oblupravlenii NKVD, NKGB, komanduiushchikh voennykh okrugov, ot 14 fevralia 1946 g.," Tsentral'nyi Derzhavnyi Arkhiv Hromads'kykh Ob"'iednan' Ukraïny (TsDAHO), f. 1 TsK Kompartii Ukrainy. Osobyi sektor. Sekretnaia chast’, op. 23, d. 2884, 1.39.

49. Data for seven oblasti in West Ukraine compiled from reports in GARF, f. R-9478, op. 1, d. $349,1.1 ;$ d. 352, 11. 69-77.

50. The popular response was summarized in regular reports. See, for example, a report of Drohobych obkom Oleksenko to Khrushchev, dated 27 December 1945. "O reagirovanii naseleniia i banditov na vyselenie semei banditov,” DALO, f. 5001, op. 6, d. 53, 11. 233-234 (1.233). 
accelerated. By the end of 1947, a total of 26,644 "rebel families" - 76,192 persons - had been deported from the seven oblasti of West Ukraine to the Soviet Far East: 18,866 men; 35,152 women; and 22,174 children - meaning that women and children dependents outnumbered their adult male counterparts by more than three to one. In a resolution dated 10 September 1947, 21,380 families - 61,814 persons - from West Ukrainian oblasti were assigned work in coal-mining operations in the Soviet Far East. ${ }^{51}$ Deportation meant intrinsically that Soviet law would punish not just suspected rebels, but also their families as well.52 Caught within this catch-22 imposed by a brutal Soviet occupation policy, women and girls increasingly joined the ranks of the Ukrainian anti-Soviet rebel underground.

\section{Women spies}

The gender shift in rebel procedures dictated a distinct Soviet tactical response: to destroy the Ukrainian underground through its female-dominated liaison networks. While a series of factors on and off the battlefield had provided new opportunities for women among the Ukrainian rebels, the growing reliance of rebels on women and girls also provided new opportunities for Soviet security forces to infiltrate and liquidate rebel forces through the use of ethnic Ukrainian women spies.

To counter the newly perceived threat associated with women, the Soviets instituted systematic raids and repeated mass arrests of local Ukrainian women. In doing so, the Soviet police pursued two main objectives. First, consistent with Soviet agentura tactics generally, they worked to sow suspicion within the ranks of the rebel underground: by arresting virtually everyone, the Soviets undermined rebel vetting procedures, and made it very difficult for the rebel SB to verify cadres. Second, the Soviet goal was to find the proverbial needle in a haystack: in the course of arresting and interrogating large numbers of women in the underground, Soviet police evidently treated every detained Ukrainian woman or girl as an enemy. Guilty or innocent, local women faced interrogations that were at the very least terrifying, but more often brutally violent, and in which the Soviets imparted a

51. Top secret report of MVD Kruglov to Stalin and Beriia, dated 7 February 1948. GARF, f. R-9401, op. 2, d. 199, 11. 205-209. The West Ukrainian families were relocated under the rubric of Sovnarkom resolution No. 35, dated 8 January 1945, regarding political deportation or spetspereselentsy. In October 1947 alone, 13,592 persons from the organs and armed forces of the MVD took part in mass deportations of members of families of suspected active rebels. GARF, f. R-9401, op. 2, d. 199, 11. 288-298; GARF, f. R-9479 Otdel spetsposelentsev NKVD SSSR, op. 1, d. 257 "Svodnye statisticheskie dannye"; and "Dokladnaia zapiska o provedennykh meropriiatiiakh po obespecheniiu vyseleniia semei aktivnykh natsionalistov banditov," MGB-Ukraine Savchenko to L. Kaganovich, dated 14 October 1947. RGASPI, f. 81 Kaganovich, Lazar' Moiseevich (1920-1957 gg.) [1893-1957], op. 3, d. 129, 11. 226-232.

52. The most comprehensive study to date of Soviet deportation policy is I. V. Alferova, "Gosudarstvennaia politika v otnoshenii deportirovannykh narodov (konets 30-kh - 50-e gg.)," Dissertatsiia kand. ist. nauk, Moscow: Moscow State University, 1998. Cf. Terry Martin, "The origins of Soviet ethnic cleansing," The Journal of Modern History, 70, 4 (December 1998): 813-861. 
sense of "knowing" the arrested woman had actively worked with the underground. If the woman detainee was actually innocent, from the Soviet point of view, no harm was done: a few days later, she would be released, battered but free. And her experience would have the added advantage of intimidating any future collaboration with rebels. But if the woman was guilty, the systematic cycle of sleep- and food-deprivation, isolation (including incarceration in a dark room with executed corpses), brutalization, and intimidation usually broke the prisoner. ${ }^{53}$

The texture of women's experience in the Ukrainian underground is best understood by looking closely at the interweaving of private and service lives of women rebels. Intrinsically anecdotal, each life represents in itself a powerful illustration of the complexity of the era, and of the often elusive series of factors that transformed some Ukrainian women rebels into Soviet siksoty, or secret agents.

Against a background of wholesale violence and abuse, interrogation and agent recruitment took on numerous subtleties and variations. Soviet police files offer us valuable insights into the complex process of siksotka recruitment, and the factors that motivated ethnic Ukrainian women to betray their former cohort in the nationalist underground. An especially useful case study is the story of the arrest, interrogation, and recruitment of Liudmilla Foia, an ethnic Ukrainian woman who survived repeated rape, beatings, and interrogations for over two months, but was only "turned" when her parents were implicated. Foia's case is especially revealing because of the virtually unprecedented quality of her files: in the archives appear not only her Soviet police records, but also the records of her subsequent interrogation by the Ukrainian rebel underground, captured two weeks later in a Soviet raid.

Liudmilla Foia was born 3 September 1923 in the village of Topora, Ruzhanskyi raion, Zhytomir - in central Ukraine. The unmarried daughter of an ethnic Ukrainian school teacher and war veteran who had served in the Austrian army from 1914 and the struggle for Ukrainian independence in 1918, Foia became a member of the OUN in 1942, at the age of nineteen. Subjected to three months of incarceration, brutality, rape, and deprivation, Foia was turned as an agent of the NKGB in April 1944, when her interrogators delivered an ultimatum: work with us, or your family will be made to suffer for your obstinate resistance. She operated under the code name "Aprel'ska" until her detention by the Ukrainian SB at the end of May 1945.54

53. Here, the texts of Soviet police files differ markedly from claims presented in post-Soviet memoirs of detained Ukrainian women. I have yet to find a single account left by a detained woman (or man) where she admits to having been broken during interrogation. In contrast, Soviet records suggest summary execution was standard practice for non-cooperative prisoners, and moreover that most prisoners did, as we would expect, break during Soviet interrogation.

54. The record of Foia's biography is preserved in the case files for a failed NKGB penetration operation against the northwest sector of the OUN-UPA in 1945. GARF, f. R-9478, op. 1, d. 643 , 11. 237-311. The file includes Foia's records with the NKGB, plus the transcripts of her interrogation by the Ukrainian underground, plus similar records for two other Soviet doubleagents apprehended in the sting. The file also includes a perceptive analysis of the failed operation by Lt.-Col. V. Konstantinov, Deputy Director of GUBB's First Department.

Elsewhere I have described the pivotal role played by Aprel'ska in a failed Soviet MGB penetration operation in 1944-1945. See J. Burds, "Agentura," art. cit.: 121-123. 
Unlike so many other women siksoty who collaborated with the Soviets, Foia was not executed following her apprehension by Ukrainian rebel counterintelligence. Recognized for her beauty and her integrity, Foia candidly responded to questions, and in the course of her ordeal managed to win the respect of her interrogator, the commander-in-chief of the UPA, Roman Shukhevych. Shukhevych was so impressed by Foia that he enlisted her into underground cultural work, and sent her to deliver lectures about her personal experiences to Ukrainian women's groups throughout West Ukraine. From this point, we lose track of Foia in the Soviet files.

Alas, other Soviet women agents were not so fortunate. Alla Linevych, agent "Galka" in Soviet files, was only eighteen when - in October 1944 - she was arrested following a denunciation by a local member of the OUN during Soviet interrogation. An ethnic Ukrainian woman from village Bol'shaia-Tseptsevychy, Vladimiretskyi raion, Rivne oblast', she was at the time of her arrest a low-ranking member of an OUN communications network in her native region. She drew the attention of Soviet officers not just because she was beautiful, well-spoken, and smart, but also because she was very well-connected. Her forty-year-old brother, Aleksei Linevych, was a former deputy commander of the UPA's Kora band in their native region, and had recently been appointed commander of the local SB unit Barsuka. One of Galka's closest friends was Mariia Demydovich (alias: "Rusal'ka") an ardent Ukrainian nationalist who was chief of OUN communications in Sarnenskyi, Rafalovskyi, and Vladimiretskyi raiony. ${ }^{55}$

Galka's first assignment was to recruit her brother, agent "Burak," into Soviet intelligence work, which she did successfully in October 1944. Soviet files here and elsewhere refer only to "verbovka agentov" - agent recruitment - and generally fail to mention that most recruitments were accomplished with threats to loved ones, holding family members hostage until a written oath was taken by the $o b^{\prime \prime} e k t$ or target of recruitment, and then that oath was proven in a Soviet operation. Active service was generally considered the line of demarcation or "point of no return" for ethnic Ukrainian collaborators, since acts against the nationalist underground carried with them an automatic death sentence to be carried out by rebel punitive units not only against the agent, but also against his or her family as well. Agent files reveal a disturbing pattern: male or female, young or old, once a person was targeted for Soviet recruitment, few could resist. Which was why so many OUNUPA rebels chose to fight to their deaths, or even to commit suicide, rather than to be captured alive. The Soviets evidently had a relentless capacity to break rebels once captured, and the overwhelming majority - men as well as women - were usually turned into Soviet assets.

Having successfully recruited her own brother for the NKVD, agent Galka's second assignment powerfully reveals the brutally tragic lives of Soviet siksoty. On

55. Biographical information for Agent Galka has been drawn from her agent file. GARF, f. R9478 , op. 1, d. 487 "Materialy o rabote spetsgrupp, deistvuiushchikh v zapadnykh oblastiakh U[krainskogo] SSR (1945 g.),” 11. 53-54, 59. The operation was run by NKVD officer of state security, third rank, Riasnoi, future deputy director of the Soviet MVD. 
2 November 1944 Galka was ordered to murder her close friend Rusalka, which she did early morning on 11 November in Tseptsevychy forest with a shot from a Soviet-provided pistol. A Soviet spetsgruppa handled disposal of the body. The Soviets intended the murder to open the way for one of their own agents, ideally Galka herself, to step into the position of chief of rebel communications in that sector. That Galka herself should have been forced to carry out the murder was a normal part of Soviet agent recruitment: transforming ardent rebels into faithful agents by forcing them to perpetrate unforgivable acts against their own. With this baptism in blood, agent Galka was both psychologically and physically ready for more complicated operations. This Soviet figurant - Russian for "stage performer" but also an NKVD euphemism for an agent performing in a field operation - was ready to dance.

Unfortunately for the Soviets, and for Galka herself, their plans to infiltrate her into the Kora band with the aim of its eventual liquidation (razlozhenie) were foiled. It seems that even as one Soviet NKVD team was positioning GalkaLinevych to infiltrate the Kora band, another NKVD team was trying to accomplish the same task with their own agent Galka, formerly "Kapustianskaia," one Anastasia Spitsyna, recruited in late 1944 and sent against the Kora band in December. Less well-prepared for the tasks ahead, Galka-Spitsyna apparently gave herself away almost immediately, and was subsequently detained and interrogated by the rebel SB. The problem was that Soviets had received intelligence from one of their informants that their agent Galka had been unmasked. In an effort to rescue the operation, Galka-Linevych was called back.

As a result of her abrupt removal from the field, Galka-Linevych's cover was blown; she was, in NKVD parlance, rasshifrovana. Rebel reprisals were brutal and immediate. Her brother Aleksei was detained by the rebel SB, interrogated, tortured, and sadistically murdered. Her mother and aunt, who lived in village Tseptsevychy, were assassinated, their corpses desecrated in the normal way vengeance was meted out to family members of traitors. All of the family's possessions were either destroyed or carried away by a rebel band. Following standard SB practice, the Linevych family name was forever annihilated in that village.

Soviet case files for agent Galka-Linevych end there: with the demoralized and terrified Galka hidden away in a Soviet safe house in Rivne, awaiting her next instructions. A mere eighteen and a half years old, she was already directly responsible for the murder of her best friend, and indirectly responsible for the deaths of her beloved brother, mother, and aunt. But her Soviet controller still had further plans for her, and it was clear from her case files that "she would be used [again]" - literally "used," budet ispol'zovana - "for operations against the OUN underground." 56 
Ostensibly, agent Galka-Spitsyna fared better. The SB commander who interrogated Galka-Spitsyna persuaded her to write a harshly anti-Soviet note to the Vladimiretskyi raion NKVD chief. Attached to the note was a communication from the SB commander to the local NKVD chief indicating that Galka-Spitsyna's life would be spared. He taunted: "You should not think that Ukrainian insurrectionaries cut off the heads of Russians and others because of their nationality. No. We Ukrainians love the peoples of other nations, but despise your communes and collective farms." ${ }^{57}$ Though the NKVD made an active effort to apprehend Galka-Spitsyna, those operations were unsuccessful. The search continued for some months, but the Soviets lost all trace of her.

\section{The rebel response: liquidating the women's threat}

"Anyone who helps the Stalinist clique will be drowned in the blood of the [Ukrainian] people."

OUN-UPA Instructions, October 1946..$^{58}$

Soviet success at infiltrating the Ukrainian underground through women spies forced the rebel leadership into a powerful conundrum: absolutely dependent on women and girls, how was the underground to rid itself of the threat posed by suspected "weak" or "treacherous" cadres - especially (in their view) women who had been turned by Soviet perfidy? The cold ingenuity of the Soviet tactics consisted not so much in the ruthless application of violence, but in the effectiveness with which the Soviet special police units provoked a palpable atmosphere of suspicion within the rebel underground. Violence begot violence, and Soviet recruitments of local siksoty provoked a bloodbath of rebel reprisals against members of their own cohort, especially against young ethnic Ukrainian women and girls. This was an intrinsic part of Soviet dezorganizatsiia, or disorganization: to force the rebels to violate their own rules of engagement; to provoke the underground into escalating the terror against their own cohort, with the inevitable result of sowing suspicion and distrust within organized resistance, and driving a wedge between rebels and the local civilian population.

The cultural milieu of the rebel underground fighter played directly into the hands of Soviet provocateurs. For the underground war in West Ukraine was driven by a distinct machismo, one that preached loyalty unto death as its most sacred rule. The confrontation between Soviet cadres ready to stop at nothing to crush the underground, and rebel leaders who preached martyrdom as a sacred duty of national patriotism, created the setting for scenes like this one, where a former member of the Soviet special forces in West Ukraine bragged among fellows in the Higher Party School in Moscow in summer 1945: "I hung one nationalist upside

57. Top secret report from GUBB Lt.-Col. Gritsenko in Rivne to Leont'ev and Zadoia in Moscow, dated 22 February 1945. GARF, f. R-9478, op. 1, d. 487, 11. $62-63$.

58. DALO, f. 5001, op. 7, d. 220,1.143. 
down and burned him on a slow fire; I cut pieces of flesh out of him [...] and he, that son of a bitch, died shouting 'Glory to Ukraine!' What a son of a bitch! How many of them I tortured!" 59

In the face of Soviet terror, all Ukrainians - men and women alike - were expected to bear the strain with stoic bravery. To communicate that message, the Ukrainian rebel leadership had even prepared a special Handbook for underground partisan warfare to assist in the proper training of nationalist soldiers. The Handbook contained stark images of real-life experiences of the true underground warrior:

"There are various tortures. Regular beatings, sleep deprivation, water torture, other physical tortures (needles under fingernails, fingers between doors, tearing out of hair...) and finally moral tortures ([the promise of enticements like] money, foreign passports, family, ideas...). A lot of them. One has to be ready for them by now and in full consciousness (without hesitation) to tell oneself this cardinal ninth point of our ten commandments - 'Neither entreaties, nor threats, nor torture, nor death will force me to betray secrets."'60

Countless other instructions echoed the same basic message: "Prohibit underground cadres from operating alone. Everyone should be assigned to a designated unit, ready to fight to the very end, and should know that no one should surrender alive into the hands of the [Soviet] enemy." 61

In such a context, surrender was construed as an act of treachery punishable by death - with underground reprisals often carried out not only against the one who surrendered, but likewise against his or her family members as well.

There was widespread expectation that captured women rebels would toe the line, martyring themselves or committing suicide rather than surrendering alive to the Soviet enemy. While countless instructions reminded men and women rebels alike of the sacred code of struggle unto death, one can also observe a concerted effort of the rebel leadership to wean themselves of their dependence on women cadres. A close investigation reveals a rather remarkable evolution of rebel attitudes: from a general consensus of the unsuitability of women for most kinds of rebel work up to 1944; the

59. Words of a student in the Higher Party School in Moscow, as reported by Ukrainian film director Oleksandr Dovzhenko in his diary, entry dated some time between 30 June-11 July 1945. Cited in the Introduction to Litopys UPA, Vol. 1 Vydannia Holovnoho Komanuvannia UPA (Kyiv-Toronto: Litopys UPA, 1995), ix, xx. Extract originally published in Aleksandr Dovzhenko, “Dnevnik. 1945, 1953, 1954,” Iskusstvo kino, 9 (1989): 48.

60. From the 29-page partisan handbook produced in 1942: I. I. Zdorovenko, Sanitarni vkazivki v naglikh zakhvorinniakh (populiarnyi doklad). There are several soiled copies in Derzhavnyi Istoricheskyi Arkhiv L'viva (DIAL), f. 201, op. 1t, d. 269. This section is based on the version appearing in 11.32-47. The quote appears on 1.46.

I. I. Zdorovenko was one of several aliases of Vasyl Kuk, high-ranking officer of the OUNUPA. Though he preached suicide before surrender, Kuk was himself captured alive, served 25 years in Soviet prisons, and was released after serving his full sentence in 1972. He still lives today in Kyiv, Ukraine.

61. OUN-UPA instructions dated 10 October 1944, translated and copied to Stalin's "Special Files" by the MVD. GARF, f. R-9401, op. 2, d. 92,1.52. Emphasis in the original. 
sudden reliance on women for numerous tasks after the arrival of Soviet forces in West Ukraine in July-August 1944; and a growing resentment towards women in key rebel positions as Soviet intelligence more and more successfully infiltrated the rebel underground by forcing ethnic Ukrainians (men, women, and children alike) into agentura or Soviet-operated informants' networks. ${ }^{62}$ By the end of 1946, a backlash from within the rebel underground greatly curtailed or rolled back women's roles in key branches of the underground rebel force.

That backlash began within individual units. For instance, the commander of an SB unit, "Stepan," ordered members of his unit to "discharge women from work in the organization." 63 Similarly, the last of eight points of instructions distributed in late 1946 on the need for strict conspiracy among members of the rebel underground emphasized the particular danger posed by women: "Do not speak with girls about organizational questions. Try to avoid them. The [Soviet] enemy specially sends women in order to initiate a love connection with members of the OUN, using her [sic] to obtain information. More than once through marriage 'revolutionary' activity was transformed into an aid to the enemy, and in this way [careless rebels] have paved their own way to their deaths." 64

Yuriy Tys-Krokhmaliuk, who wrote the Ukrainian diaspora's definitive military history of the struggle against the Soviets during and after World War II, likewise identified the chief threat of Soviet infiltration as "sending young girls into the insurgent areas to gain influence through their sex over UPA commanders or OUN leaders with the purpose of helping [the Soviets] apprehend or kill them." 65 Spending long winters in the underground, rebel soldiers were deemed easy prey for these classic espionage "honeytraps." But the threat of romantic entanglement was just part of the intrinsic threat associated with the backlash against women in the underground. Subsequent instructions stipulated that all women, not just potential romantic partners, represented a perceived security threat for male rebels. Hence, some rebels - the members of Self-Defense Units (VKS) were singled out particularly - were strictly prohibited from visiting their womenfolk at all: "The VKS member has no right [...] to visit his mother, wife, children, girlfriends." 66

62. The pattern of accepting women's changing roles during times of need or crisis, then reverting back to traditional antagonisms once the crisis has passed, has been observed in numerous studies of women's roles in social movements. The very best of a large number of works on this theme was written by Joan B. Landes, Women and the public sphere in the age of the French Revolution (Ithaca: Cornell University Press, 1988). Landes shows that French women's opportunities were extensive on the revolutionary barricades, but the same women were expected to return to traditional gender roles once the revolution was won.

63. Instructions seized from the corpse of an OUN rebel killed in a firefight on the night of 27 May 1945 in Kalushskoi okrug. GARF, f. R-9478, op. 1, d. 292,1. 66.

64. TsDAHO, f. 1, op. 23, d. 2968,1. 203.

65. Yuriy Tys-Krokhmaliuk, UPA warfare in Ukraine: Strategical, tactical and organizational problems of Ukrainian resistance in World War II (New York, 1972): 284.

66. From "Instructions for Self-Defense Units," a copy of which was forwarded from NKVD Ukrainian SSR Riasnoi to L. Beriia in a top secret report dated 1 December 1944. GARF, f. R9478, op. 1, d. 292, 11.319-324 (1.324). 
Likewise, by the end of 1946 the long-standing rebel relay courier system of communication was replaced by a new network of "dead drops" - hidden locations where the two principals were the only ones to know the location. This was designed to reduce Soviet access to written rebel instructions, plans, and communiqués. But it was also a reflection of the general perception in the OUNUPA leadership that the weakest links in rebel operations were sectors depending largely on women. Since over $90 \%$ of the underground's liaisons had been women, the "dead drop" communications network would remove vulnerability to alleged "weak women" from vital rebel operations.

A similar strike against perceived "weak women" was the reorganization of the Ukrainian Red Cross (UChKh) that, until 1946, provided primary medical support for underground cadres. The Ukrainian Supreme command's instructions were explicit: "Instead of women, men are to be trained in special medical courses."67 The organization of an independent male-provided medical service within the underground undermined yet another channel the Soviets had used to track rebels.

\section{Rebel death squads}

"We warn Ukrainian citizens: anyone who works with the organs of the NKVD-NKGB, all those who by any means whatsoever work with the NKVD [...] will be considered traitors, and we will deal with them as with our greatest enemies."

UPA Instructions, 11 July 1945.68

"We were not intimidated by the screams or suffering [of our victims]. [...] I don't remember the last names of the people we killed. [...] I know they were all [ethnic] Ukrainians, local people."

From the Soviet interrogation transcript of Rivne SB executioner A. Kiriliuk, December $1944 .{ }^{69}$

Even as women were being pushed out of underground work by late 1946, the Ukrainian rebel underground ruthlessly punished suspected betrayal. As early as 1944, as the underground became more and more dependent on women, special death squads were formed to liquidate women suspected of collaboration or fraternization with Soviet soldiers and officials..$^{70}$ Underground reprisals were, here as elsewhere, swift and brutal. As one Ukrainian peasant recalled, Ukrainian

67. TsDAHO, f. 1, op. 23, d. $2967,1.45$.

68. GARF, f. R-9478, op. 1, d. 292,11. 29 ob. As cited in J. Burds, “Agentura,” art. cit.: 104.

69. GARF, f. R-9478, op. 1, d. 128, 1. 227. On following orders, see the testimony of former teacher and OUN officer Petro Mikitenko, in a Soviet interrogation transcript dated 20-25 May 1944: "In the OUN there exists the principle of vozhdizm (dictatorial rule). The commander's order is law for his subordinates." GARF, f. R-9478, op. 1, d. 134, 1. 36.

70. On rebel terror units generally, see the author's discussion in "Agentura," art. cit.: 104-111. 
underground "rebels brutally murdered my wife, my child, and my best friend. Why did they murder them?"71 The Ukrainian peasant Bertsiuk from Krakovetskyi raion complained that rebels had "murdered my wife and two young children. They burned my house and [ruined] my whole farm."72

The standard SB death order reflected the emergence of particular forms of "women's treachery." Typical was this "List of secret collaborators [with the NKVD] in Region 4," a Ukrainian rebel SB document seized by a Soviet special forces unit in Zolochiv raion in late 1944. It is not without significance that six of eight of the names on the typical list were local women denounced by neighbors sympathetic to the OUN:

“2) Woman of village Rozvazh MORTSA Yuliia, [ethnic] Ukrainian, in 1941 was a member of the Communist youth (komsomolka) and an informer for the NKVD. When the Soviets returned in 1944 she began to work still more actively, denouncing the local officer-in-charge or the provisions expert, [reporting] what he was doing, whom he was meeting. She informed about everything to the NKVD and the president of the raion. [...] Every day she would stroll with [members] of the NKVD, and [once was heard to] shout 'Down with the Banderivtsy!' She informed against everyone who joined the UPA.

3) Woman of village Rozvazh POPIUK Olga, Ukrainian, was connected to the partisans in our village. She informed some [Communist] prisoners about our entire movement. When the Soviets returned she began to report who did what in the village, that there were meetings and who attended. She informed against the families of those who joined the UPA. She informed the NKVD and the local communist party about all this, reporting who among the youth were hiding from forced levies, who had deserted from the [Red] Army, or escaped [forced] labor in the Donbass. She [was heard to] say that the end [was near] for us and for [independent] Ukraine.

4) Woman of village Rozvazh MIKHAILIUK Yuliia, ethnic Russian, ${ }^{73}$ was connected with the Poles and the Soviet partisans, and now has become a major informer for the NKVD. She informs against those who collaborated with the Germans, [and] who is still hiding out. She informs the NKVD and the local party representative about everything that happens in the village. She [was overheard] saying: 'Down with the Banderivtsy! Now it's time to start living the life we've all been waiting for. To hell with you and your Banderivtsy!'

5) Woman of village Rozvazh LYTARCHUK Fima, ethnic Ukrainian, works as a secret agent of the NKVD, reports about who is in the village, who is hiding out, and has betrayed many friends - both men and women. She reports who collaborated with the Germans, and what they did. Has a very strong connection with the president of the village soviet and the president of the local party apparatus. She's been squeezed many times by the NKVD and the local party representative. She gives everything away: who appears in the village,

71. DALO, f. 3, op. 1, d. 212,1.114.

72. Ibid., $1.156 \mathrm{ob}$.

73. The name is actually Ukrainian, which suggests she was probably the offspring of a mixed marriage: Russian mother, Ukrainian [or East Ukrainian] father; or that she was a Russian married to an ethnic Ukrainian. Such mixed families were often targeted by rebel suspicion of pro-Soviet collaboration. 
who is hiding out. [She was overheard] to say: 'Down with the Banderivtsy! We've waited long enough for freedom. Now it's time to live!'

6) Woman of village Rozvazh BRONOWICZKA Marianka, ethnic Pole, works as an informer for the Polish [underground] and the NKVD. Was connected with the local police. Has informed against those who are hiding out, who returned from the [underground] army or ran off from [forced] labor in the Donbass. [Was overheard] saying: 'Down with Ukrainians and down with Banderivets families!'

7) Woman of village Rozvazh PUSHKA Agaf'ia, Ukrainian, betrayed everyone - who collaborated with the Germans, what sort of work they did [during the German occupation], that there were meetings and who attended the meetings. She gave away those who are hiding out from the [forced enlistment] levies, who has deserted from the [Red] Army. She has betrayed many friends men and women - to the NKVD: who has weapons, who runs the meetings and where. She has informed about the whole movement, everything that's happening now, and [has been overheard] to say: 'Down with the Banderivtsy!'

\author{
[Signed] ZEVERUKHA. \\ Glory to Ukraine! \\ Glory to her heroes!"74
}

Obviously tenuous and riddled with hearsay, such “documented proof” of a woman's alleged betrayal began the process of liquidation. The target lists were themselves based more on denunciations by neighbors, or misconstrued rumors, than on solid intelligence. Nonetheless, every one of these women was brutally executed within weeks of appearing on the underground's target lists. Regardless of the unreliability of the evidence, makeshift rebel courts, closely tied to SB assassination teams, did, as a rule, order summary executions, with little delay between verdict and execution. There follows an example of a typical rebel death sentence:

\title{
VERDICT
}

"On the 19th day of October 1944 this court of the military tribunal [of the Ukrainian Insurrection Army], having reviewed the case against MIRONCHUK Tat' iana and having found her guilty of collaboration with the NKVD, and on the basis of her confession this court hereby sentences MIRONCHUK Tat iana to death.

[Added below]

This sentence was carried out on 19.10.1944 at 5 o'clock in the morning. Glory to Ukraine! Glory to her heroes!"

[Two signatures]

Kom.

Pol. Berezhniuk 75

74. GARF, f. R-9478, op. 1, d. 126, 11. 327-328. In 1939, village Rozvazh - Zolovhiv raion, L'viv oblast' - had a population of 1,050. It is interesting that the author of the denunciation was a woman. In a comparable situation, white women in the American south were formally banned from Ku Klux Klan membership, but nonetheless utilized Klan support for their own personal ends. See Nancy Maclean, "White women and Klan violence in the 1920s: Agency, complicity and the politics of women's history," Gender and History, 3,3 (Autumn, 1991): 285-303.

75. GARF, f. R-9478, op. 1, d. 126,1. 329. 
An especially macabre ritual of rebel execution was that nearly every person charged was, as a rule, first made to confess his or her treachery. During his own interrogation by the Soviet NKVD in November 1944, the commander of one of these special death squads, Iosif Pan'kiv, described the circumstances under which such confessions were extracted:

"At the end of February 1944 I learned that an actress in the L'viv opera theater - Maria Kapustenski - was allegedly connected with the Gestapo and had betrayed another actor, a member of the OUN.

With the consent of the SB leadership she was kidnapped by my own people in the unit and brought to a shooting-range, where we had earlier prepared a place for her interrogation.

She was kidnapped outside the [L'viv opera] theater and brought directly to the site. I personally interrogated her.

[Initially] she categorically denied any connection with the Gestapo. So then we stripped her naked and with willow-switches we had earlier prepared, each man in my unit beat her until all we had left was one shredded switch. Then she said she would confess.

After this [beating], she 'confirmed' that she had had a connection with the Gestapo. Then, under my orders, she was dragged 500 meters from the site of the interrogation and shot by [rebel soldier] GLUKHYI."76

Pan'kiv took evident pride in his work, confessing to similarly bloody assassinations of at least sixty ethnic Poles - suspected German or Soviet "collaborators" - during the war. ${ }^{77}$

Soviet investigative files are filled with references to follow-up investigations of brutal reprisals carried out by rebel SB units against women suspected of proSoviet sympathies. "In village Diad'kovichi [underground rebel units] murdered Sof'ia PAVLIUK, who heartily welcomed soldiers of the advancing Red Army."78 "On the night of 19 September [1944] in the village Bol'shaia-Osneshcha, Kolkovskyi raion the STRESHA band murdered four women, in whose apartments lived Red Army soldiers."79 "On the night of 23 September [1944] in village Mikhlin, Senkovichi raion, a rebel unit of four persons killed four women and injured one. [The women] had gotten together to write letters to their husbands and sons [serving] in the Red Army." 80

76. See the extraordinary top secret transcript of the interrogation of Iosif Pan'kiv, referent of the SB in L'viv city and simultaneously rezident for German counter-intelligence (Gehlen Org), conducted by NKVD Lt.-Col. Zadoia on 28 October to 2 November, 1944. GARF, f. R9478, op. 1, d. 135, 11. 156-246 (11. 183-184).

77. Ibid., 1. 182. In Pan'kiv's case, it is evident that other forms of coercion were applied to get him to speak freely during his interrogation. "I intend to hide nothing from the organs of the NKVD, since I understand that on this depends not only my own life but - and this is what disturbs me - the life of my family" (1.157).

78. GARF, f. R-9478, op. 1, d. 128,1.226.

79. Ibid., 1. 228

80. Ibid. 
While targets of underground rebel violence were certainly not exclusively women and girls, a close look at patterns of rebel violence against local citizens suggests that reprisals against "collaborators" was a euphemism for violence against ethnic Poles during World War II and the first two postwar years, when three quarters of the violence against "locals" was directed against ethnic Poles. Following the forced deportation of over 100,000 ethnic Poles from West Ukrainian oblasti in 1945-1946, however, available evidence suggests that as many as four of five of victims of rebel violence against suspected "collaborators" were ethnic Ukrainian women, especially young women suspected of sexually fraternizing with men of the Soviet occupation. ${ }^{81}$ These so-called "moskal' ki" - a derogatory term describing certain ethnic Ukrainian women or girls as "Red Army whores" - were among the most hated and resented categories of Ukrainian enemies. A member of the Rivne raion SB, A. Hritsiuk, apprehended by Soviet police in late 1944 following a denunciation by a local woman, left the typical confession regarding the rebel drive to annihilate suspected moskal $k i$ :

"In mid-January 1944 in the village of Iasenichi, on orders of [my unit commander] 'DUBA,' I murdered a 19-20 year-old woman from the village, Ukrainian by nationality.

The murder was perpetrated by means of hanging with a noose [putovaniem (literally: 'stringing her up')]. The corpse was buried by [local] inhabitants at the site of the execution. [...]

At the end of January 1944 in [...] village Hrushvitsa I took part in the murder of another woman, hanging her with the same noose [the Soviet NKVD] had used to execute members of the raion SB units 'NECHAI' and 'KRUK'."

For perpetrators, victims, and bystanders alike, reprisals were intimate acts of terror against well-known targets. Hanging was the favored form of ritualized public execution when rebels perceived some popular support for their action, followed in particularly heinous cases of perceived betrayal by the victim - with ritualized desecration of the corpse. ${ }^{83}$

Often, orders to execute suspected women "collaborators" were issued well in advance, and then systematically carried out by specially organized units. One such SB unit specially designated for carrying out reprisals against suspected moskal' $k i$

81. Aggregate figures calculating victims of rebel terror do not provide statistics on gender. These data are based on estimates gleaned from operations reports and rebel target lists from 1946-1948

82. GARF, f. R-9478, op. 1, d. 128,1.227.

83. On corpse desecration, see J. Burds, "Agentura," art. cit.: 104-111. Soviet records do not generally include information that would allow for a close study of gender-specific forms of corpse desecration. See the materials on Bosnian genocide in Natalie Nenadic, "Femicide: A framework for understanding genocide," in Diane Bell and Renate Klein, eds, Radically speaking: Feminism reclaimed (Melbourne: Spinifex, 1996): 456-464. 
was discovered operating in L'viv in June $1948 .{ }^{84}$ On 21 June 1948, a cleaning woman at L'viv State University (today, Ivan Franko University in L'viv) was dumping waste in the university stable when she caught sight of a pile of severed human legs. In horror, she immediately summoned the police. Upon further investigation, Soviet investigators uncovered eighteen naked and mutilated corpses - seventeen women and one adolescent boy. As a member of the unit who confessed during MGB interrogation recounted:

"The members of the unit [operated] on orders of the OUN underground. From November 1947 we systematically assassinated persons loyally disposed to the Soviet regime who lived in regions near L'viv city. With this purpose we met with those marked for liquidation at the L'viv railway station or the town bazaar, luring them on various pretexts to the stables at L'viv State University. There we killed them with blows [wielded] by a blunt instrument to the [back of the] head." 85

Nearly all of the corpses were so badly decomposed that only six could be identified by family members (mainly through personal objects or clothing). ${ }^{86}$ Each of these six could be linked in some way or other to suspicion of pro-Soviet activity or fraternization. Details from the list will illustrate the often tenuous reasons for which SB vengeance was applied:

- MOISIN, Marina, born 1930, age 17. Murdered 8 April 1948. Two cousins of MOISIN had served in the Red Army. MOISIN had been observed regularly bringing milk for sale to a building where agents of the MVD-MGB lived.

- MIRON, Maria, 23 years old. Refugee from Poland. The SB order for her execution contained only a general indictment: 'Loyally disposed to the Soviet regime. Promptly fulfilled all obligations to the state.'

- BUIANOVSKAIA, Maria, born 1922, age 25. Murdered 16 June 1948. BUIANOVSKAIA was deported to Germany for forced labor from 1942 to 1946. Her brother had served in the Red Army and had been killed at the front.

- IVANISHINA, Anna, born 1908, 39 years old. Murdered 30 May 1948. Her sister's husband had been labeled a Soviet collaborator by the underground

84. Top secret report of Chief of GUBB-Ukraine Colonel Sergienko in Kyiv, July 1948. GARF, f. R-9478, op. 1, d. 1285,11. 19-26. The original discovery warranted a speedily sent top secret telegram from Deputy Director of MVD Ukrainian SSR Major-General Bulyga to Soviet MVD S. Kruglov in Moscow, dated 24 June 1948. GARF, f. R-9401, op., 1, d. 2973, 11. 152153. In pencil across the top of the telegram, Kruglov wrote: "C[omrade] Serov. PI[ease] meet with me. Kruglov." This communication demonstrates the perceived importance of the case. There was a subsequent top secret summary report from Ukrainian MVD Strokach to Soviet MVD Kruglov, dated August 1948. GARF, f. R-9401, op., 1, d. 2973, 11. 283-286. On the first page of this report, future KGB chief Ivan Serov wrote: "To C[omrade] Davydov. Familiarize yourself [with this document] and show C[omrade] Kruglov. [Signed] I. Serov. 30.8.48."

85. Signed confession of Kuz'ma Ken'o, 24 June 1948, contents communicated by ciphered telegram to Moscow. GARF, f. R-9401, op., 1, d. 2973,1. 152.

86. According to Soviet forensic pathologists, none of the corpses had been sexually abused. Apprehended subjects later confessed that the bodies had been stripped to prevent positive identification. 
for taking the post of president of a village soviet in 1945. Subsequently, he and his whole family were brutally murdered in an UPA raid. IVANISHINA had lived in the same house as her sister, but she miraculously escaped death during the initial raid. The SB death sentence was eventually carried out nearly three years later.

- KUKHAR', Ekaterina, born 1923, age 24. Murdered 20 May 1948. Her brother was a demobilized soldier who had served six years in the Red Army.

- MAER, Pelageia, born 1924, age 23. Murdered in April 1948. She had worked in ancillary labor during the German occupation. She and the rest of her family were transported for forced labor in Germany at the time of the German retreat in 1944. On her return to L'viv oblast' in 1947, MAER joined the local Soviet aktiv in her village. Her home was observed by OUN informants to have been visited frequently by MGB officers. ${ }^{87}$

However tenuous these charges may seem now, such minor infractions - the mere appearance of pro-Soviet collaboration - carried grave consequences: evidently, the appearance of collaboration was synonymous with an actual act of betrayal against the Ukrainian people. In each case, the victim had been beaten to death on the back of the skull with an ax, hammer, or pipe. ${ }^{88}$ As a reflection of the macabre ritual interrogation that usually preceded rebel executions of suspected collaborators, one corpse still had more than a meter of noose around her neck.

This particular Ukrainian SB assassination squad had nine members, and acted on the direct instructions of the commander of an UPA regiment based in a nearby forest in Bibrka raion. One of the university's wagoners - Kuz'ma Ken'o drove periodically to collect wood in the forest and to meet with UPA superiors who would issue him instructions for relay to the other members of the unit. All of the executions had been perpetrated under orders. Ken'o had been recruited into the unit by an old friend, Zakharyi Lychko, an officer from the Ukrainian SS Galicia Division, who was arrested by the Soviets in $1946 .{ }^{89}$

The repeated violence against women was certainly noticed and feared by the local population. As peasant A. V. Vasil'ev wrote from Stryi raion to his cousin on 1 September 1946: "Bandits cut the throats of six women in one night! It's

87. Summarized from data in GARF, f. R-9478, op. 1, d. 1285, 11. 20-21.

88. Forensic specialists suggest this sort of pattern would have indicated two possibilities: ambush, or the murderer's own discomfort with perpetrating the violent act. Since in each case murder was perpetrated in the presence of several men, it is unlikely that ambush would have been an essential part of the method of execution. Forensic pathologists suggest the act of violence was distasteful to the perpetrator, who murdered from behind - out of sight of the victim - so as not to meet the eyes of the woman designated for the kill. This is an important distinction. It suggests that SB assassins were simply following orders, murdering women designated for liquidation by others. These were not excesses of an individual unit of sadists, but fulfillment of duties of rebel soldiers. On rites of violence as indicators of perpetrator attitudes and motives, see the informative recent study of American expert, John E. Douglas, Mindhunter: Inside the FBI's elite serial crime unit (New York: Scribner, 1995).

89. GARF, f. R-9478, op. 1, d. $1285,1.22$. 
horrifying here now - you go to sleep and don't know if you'll ever wake up again." 90

Instructions in mid 1946 ordered OUN-UPA units not to murder Ukrainian women who wanted to become legal citizens - and to restrict liquidation to insubordinate cadres, collaborators, and provocateurs, and not their families. ${ }^{91}$ With the growing demoralization of the underground in the war against the Soviets, and the decline of cadre discipline, the instructions came too late to exert much influence. The initial orders to root out women spies gave way to vigilante-style retaliation against women slurred for a wide variety of reasons. More and more often, Ukrainian women were scapegoated for the growing frequency of rebel failures.

\section{Patterns of denunciation}

"I've heard about a growing number of denunciations, usually about hidden weapons. Most denunciators are women."

Dr. Zygmunt Klukowski, diary entry for 19 February $1940 .{ }^{92}$

The cycle of state-sponsored terror and rebel reprisals left the population of West Ukraine with little recourse but to develop tactics common to marginalized groups caught in the borderlands between two warring parties: in the public sphere, at least, they endeavored to appear to collaborate with either side as little as possible.

Another way of approaching the problem of women in West Ukraine after the war is to look at patterns of denunciations. There is considerable evidence in Soviet operations files to suggest quite confidently that women were in fact the primary channels for leaks to Soviet authorities regarding the whereabouts of members mainly men - in the rebel underground.${ }^{93}$ But there are two significant patterns

90. From a top secret summary of interdicted letters in Drohobych oblast' for the period 1-19 September 1946, from MGB Lt.-Gen. Voronin to the secretary of the Drohobych obkom, dated 3 October 1946. DALO, f. 5001, op. 7, d. 279, 11. 119-121 ob. (120 ob.). This report was a summary of 98 instances of Ukrainian "bandit" activity from 21,325 pieces of mail read by MGB censors.

91. TsDAHO, f. 1, op. 23, d. 2968,1.54.

92. Zygmunt Klukowski, Diary from the years of occupation, 1939-1944 (Urbana: University of Illinois Press, 1993): 77.

For an interesting comparative perspective of "Judas-women" - women denunciators in Nazi Germany, see Helga Schubert, Judasfrauen: Zehn Fallgeschichten weiblicher Denunziation im Dritten Reich (Munich: DTV, 1990). I am grateful to Alison Fleig of Harvard University for bringing this work to my attention.

93. In contrast, recent research has found that over $90 \%$ of denunciations to the East German Stasi were submitted by men. See Timothy Garton Ash, "Comparative horrors," London Review of Books (19 March 1998): 18-20; and Gisela Diewald-Kerkmann, "Politische Denunziation - Eine 'weibliche Domäne'? Der Anteil von Männern und Frauen unter Denunzianten und ihren Opfern," 1999: Zeitschrift für Sozialgeschichte des 20. und 21. Jahrhunderts, 11, 2 (1996): 11-35. 
suggested by the evidence. First, Ukrainian women collaborators by and large imparted information about loved ones with whom they were intimately connected: convinced of the futility of further armed struggle against superior Soviet forces, and operating on the hope of bringing the menfolk back home alive, ethnic Ukrainian women not infrequently passed on information to Soviet authorities. It is important to note that these were not typically anonymous, back-stabbing denunciations motivated by resentment, enmity, opportunism, or greed, but rather acts of feminine mediation motivated by concern and love. ${ }^{94}$ Caught between the seeming invincibility and ruthlessness of the Soviet campaign versus the rebel machismo of "war unto death," Ukrainian women introduced a third road aimed primarily at breaking the deadlock of violence and bringing their menfolk back home alive. As L'viv oblast' Party secretary Iakov Grushetskii reported to Khrushchev in late 1945: "The [women] peasants themselves assist the organs of Soviet power in the surrender of their husbands, brothers, sons and fathers, and likewise reveal the locations of rebels." ${ }^{95}$ A Professor Dumka at the L'viv Pedagogical Institute unwittingly explained the logic of denunciations to a Soviet informant: "[Ethnic] Poles and the Soviets are wiping out the Ukrainians. Happy are the ones who are deported [to Siberia]. Only by this means can you escape destruction." ${ }^{96}$ Under the circumstances, arrest and exile were often preferable to living in a war zone, caught between two implacable enemies.

A second feature of female denunciations of menfolk to Soviet authorities was that paradoxically the denunciations were often made at the behest of the men themselves. Far from being merely passive victims of alleged female weakness the orchestrated fiction upon which family survival depended - men in the Ukrainian underground were often the perpetrators of their own apparent demise. Why would men in the Ukrainian underground collude with their wives and other loved ones to denounce them to Soviet authorities? The subterfuge was imposed by conditions of civil war and terror, conditions that - as we have seen - labeled surrender an act of overt betrayal and which provoked brutal reprisals against the ex-rebel and his family and friends by roving SB units. Surrendering members of rebel units were absolutely clear on this point: "[The rebel officers] warned us that

94. For a useful comparative analysis of denunciations, see Sheila Fitzpatrick and Robert Gellately, eds, Accusatory practices: Denunciation in modern European history, 1789-1989 (Chicago: University of Chicago Press, 1997).

95. Grushetskii to Khrushchev, dated 17 July 1945. DALO, f. 3, op. 1, d. 212,1. 170. For similar observations, see monthly reports on the struggle against banditry in West Ukraine, TsDAHO, f. 1, op. 23, d. 1741, 11. 42-48 (1.46).

For a comparative perspective on women's survival strategies, see the insightful work of Annamarie Tröger, "Between rape and prostitution: Survival strategies and changes of emancipation for Berlin women after World War II," in Judith Friedlander, et al., eds, Women in culture and politics: A century of change (Bloomington: Indiana University Press, 1986).

96. Extracts from a top secret special communiqué from NKGB Chief in L'viv oblast' Voronin to Grushetskii, dated 19 November 1944. DALO, f. 3, op. 1, d. 212,1. 169. 
if we surrendered, they would massacre our families." 97 "The unit officers intimidate us, [saying that the Soviets] will laugh at us and massacre us and our families." 98 In contrast, to be captured or arrested was not just more honorable before rebels and neighbors, but also the sole means by which to escape the underground's "war unto death." As L'viv oblast' Party secretary Iakov Grushetskii reported to Khrushchev on 12 January 1946:

"Among the banderovtsy familiar with the state decree [of 19 May 1945 offering amnesty to those who surrender], there are many [rebel soldiers] who desire to break with their units, but they are afraid of their leaders. So they send their wives to the NKVD to inform us that they want us to arrest them. [...] Surrendering rebels declare: 'Better to join the Red Army than to know that our families will be repressed.",99

To take just one of many examples: in July 1945, the peasant woman Mariia Paliuha of Sknylov village, L'viv oblast', denounced her husband Ivan to local authorities. Ivan had deserted from the Red Army and joined an underground unit stationed nearby. Another case involved the passage of a heavily-armed Soviet special forces unit through the village of Horodyslavich in Bibrka raion (L'viv oblast '), evidently on a seek-and-destroy mission. A peasant woman who feared the ensuing bloodbath ran into the street and screamed: "I'll show you right now where the rebels are hiding. I've had enough of enduring [this violence] and of being afraid." She then led the NKVD directly to three hideouts and was personally responsible for the Soviet capture of eight rebels. At a fourth hideout, the local rebel unit commander "Rybak" was allegedly shot trying to escape. The same peasant woman likewise gave the NKVD surnames of twenty more rebels still in hiding. ${ }^{100}$

Women also denounced rebels to Soviet authorities based on their objections to the excesses of the rebel terror. In a voluntary denunciation to the NKVD in Rivne raion in late 1944, ethnic Ukrainian woman E. A. P-k angrily gave up the identities and crimes of each of the local members of the rebel SB:

"In our village at the end of 1943 a band of murderers calling themselves the SB was formed. These bandits murdered very many innocent people. I know that they kidnapped and murdered a local pharmacist and his wife, her name was Olia, that they strangled a unit of Red Army prisoners who had escaped from a German prisoner-of-war camp, and that they tortured to death the family of the [ethnic] Pole ZAVADA.

97. DALO, f. 3, op. 1, d. 212,11. 169-170. Cf. several similar statements on 11. 168-174.

On the deeper implications of communities that make a virtue of deceiving of outsiders, see the discussion in Perez Zagorin, Ways of lying : Dissimulation, persecution, and conformity in early modern Europe (Cambridge: Harvard University Press, 1990); and James C. Scott, Domination and the arts of resistance: Hidden transcripts (New Haven: Yale University Press, 1990).

98. DALO, f. 3, op. 1, d. 212,1.169-170.

99. DALO, f. 3, op. 1, d. 212,11. 115-116

100. DALO, f. 3, op. 1, d. 212,11. 171-172. 
To conceal from Soviet power and [local] people their dirty crimes, the bandits threw the murdered bodies into a well located two kilometers from Diad'kovichi village at Kurovskyi's farm."101

This denunciation was subsequently investigated, leading to the arrest, confession, and execution of four members of the Ukrainian rebel SB unit in Rivne raion: Trofimchuk, A. Kiriliuk, A. Hritsiuk, and Slobadiuk. ${ }^{102}$ In a similar case, acting out against the murders of several local ethnic Polish families by OUN units, in August 1944, a young Polish woman from village Patsykiv agreed to collaborate with the NKVD in Stanyslaviv. According to an OUN report, this young woman "betrayed to the NKVD 20 families and several other young women from village Patsykiv who had ties to the [Ukrainian nationalist] partisans."103

Soviet forces in West Ukraine often used gender as a channel to influence family members. The method of influencing rebels through their women folk was a common Soviet tactic. Ukrainian rebel wife Mariya Savchyn, for instance, was arrested in January 1949 by the MGB. Knowing that her husband was an officer in the Ukrainian resistance, the MGB released her on the presumption that she would persuade her husband to leave the underground and work for them. Instead, she exploited her release as an opportunity to go underground with her husband in Volhynia, where she remained until she was apprehended again in summer 1953. ${ }^{104}$

Similarly, the Ukrainian rebel underground tried to influence men through their wives. In instructions calling for the boycott of elections to the Supreme Soviet in February 1946, women were called upon directly: "Women, stay out of trouble, for the sake of your children - boycott the Stalinist 'elections.' Stop your husbands from voting. Death to Stalin! Death to Khrushchev! Long live the OUN! Long live the unified Ukrainian independent state!"105

101. GARF, f. R-9478, op. 1, d. 128, ł. 227 ob.

102. See the summaries and extracts from their subsequent confessions in GARF, f. R-9478, op. 1, d. 128, 11. 225-230, dated 26 December 1944.

103. See the report for 15 August 1944 from Lisets raion rebel commander Kochevik to OUN headquarters, subsequently seized by the NKVD. RGASPI, f. 17, op. 125, d. 336, 1. 181.

104. Mariya Savchyn ("Marichka”), Tysiacha dorih (spohady), op. cit.

105. OUN-UPA instructions calling for boycott of the 10 February 1946 elections for the Supreme Soviet, TsDAHO, f. 1, op. 23, d. 2968,1.216. 


\section{The meaning of violence}

"Words may be eloquent, but how much more so is silence. $[\ldots]$

Wanda Półtawska, And I am afraid of my dreams. ${ }^{106}$

"The ordinary response to atrocities is to banish them from consciousness. [...] Atrocities, however, refuse to be buried."

Judith Herman, Trauma and Recovery.

Having endeavored to identify distinct gender patterns in the civil war in West Ukraine, and having taken the step toward rediscovering Ukrainian rebel women's contributions and tragic lives, there still remains the task of explaining the conundrum with which this investigation began: how do we account for the relative silence of Ukrainian discussions of women's roles in the rebel underground, versus the Soviet accounts that emphasize women's active participation?

\section{The logic of Ukrainian silence}

In the course of researching and writing this article, I spoke with hundreds of people about this divergency between Ukrainian and Soviet accounts of women's roles in the underground movement, and received just as many different responses. It is interesting to note that nearly all those ethnic Ukrainians questioned - male or female, young or old, native Ukrainian or diaspora - agreed that we know so little about women's contributions because of Ukrainian male attitudes. Men and women alike spoke rather passionately on this theme, and often referred to a distinct male machismo among "Old World" Ukrainian men. Certainly, the leadership of the Ukrainian Insurrection Army were not the sort of men who would readily share the limelight with their women.

While it is tempting to accept such an explanation at face value, there are limits to what we can achieve by blaming traditional patriarchalism or male chauvinism alone for this long-neglected area of historical inquiry. Certainly, a record of countless female victims is hardly the stuff of which "heroic struggle" is made, even as diaspora accounts have long endeavored to transform male victims into heroes: evidently, male suffering is somehow more "courageous" and "heroic" than female suffering. Male victimologies lend themselves more readily to heroic histories. In contrast, female victims of gender violence are less likely to be viewed as heroes and more likely to be construed as reminders of defeat. This is especially so in patriarchal societies. As Gerda Lerner perceptively noted in her pathbreaking study of female subordination: "The impact on the conquered of the rape of conquered women was twofold: it dishonored the women and by implication

106. Wanda Półtawska, And I am afraid of my dreams (London: Hodder \& Stoughton, 1964) : 107. 
served as a symbolic castration of their men. Men in patriarchal societies who cannot protect the sexual purity of their wives, sisters and children are truly impotent and dishonored." 107 Descriptions of the horrific scenes of gender violence left over from ethnic nationalist brutality certainly eluded heroic imagery. As a nationalist partisan recalled: "Special treatment was always meted out to women. Rape is the male conqueror's instinctive privilege, his way of defiling and possessing his victim, and killing and sex are thus intertwined. [...] The naked remains of women often showed signs of mutilation - their vaginas had usually been slit open. Even small girls had been carved with knives and bayonets."108

The more extreme version of this "chauvinism" line would assert that having found themselves dependent on women in 1944-1945, and having faced increasing losses to the Soviets, "chauvinistic" Ukrainian men lashed out against suspected "weak women" in their ranks: increasingly stymied by Soviet forces, Ukrainian rebel men took out their anger and frustration on their own womenfolk; hence, the absence of effort in subsequent years to rehabilitate the memory of women's contributions. A broader, less judgmental amalgam of the above would identify the context of widespread violence and brutality, and see the evidence of skyrocketing violence of Ukrainian men against their own womenfolk as a characteristic symptom of their own post-traumatic stress. As a leading authority on the psychology of male gender violence has argued, "Abused men abuse women."109

And, what is equally true, there was a dearth of women candidates pushing for recognition of their own heroic status. The Latvian émigré writer Agate Nesaule put it best: "No one ever wants to hear about the painful parts of my past. People have hundreds of ways, both subtle and harsh, to reinforce my own reluctance to tell."110 The foremost American psychiatric expert on women and trauma, Dr. Judith

107. Gerda Lerner, The creation of patriarchy (New York: Oxford University Press, 1986) : 80.

108. W. Lotnik, op. cit.: 66-67. Though he was a Polish partisan, Lotnik made it clear that such descriptions could be applied equally to the carnage inflicted by both sides, ethnic Ukrainian and ethnic Polish: "The ethnic Ukrainians responded by wiping out an entire Polish colony, setting fire to the houses, killing those inhabitants unable to flee and raping the women who fell into their hands, no matter how old or young. This had been the pattern of their behaviour east of the Bug [River], where tens of thousands of Poles had been either expelled or murdered. We retaliated by attacking an even bigger Ukrainian village and[...]killed women and children. Some of [our men] were so filled with hatred after losing whole generations of their family in the Ukrainian attacks that they swore they would take an eye for an eye, a tooth for a tooth. [...] This was how the fighting escalated. Each time more people were killed, more houses burnt, more women raped" (65). Cf. Beverly Allen, Rape warfare: The hidden genocide in BosniaHerzegovina and Croatia (Minneapolis: University of Minnesota Press, 1996).

109. Jim Hopper, "Factors in the cycle of violence," Journal of Traumatic Stress, (1996): 721 743. Drawing from an extensive comparative study of statistics of criminal violence and homicide in 110 nations since 1900, sociologists Dane Archer and Rosemary Gartner found that the frequency of domestic violence dramatically increases after wars. See their landmark study: D. Archer and R. Gartner,Violence and crime in cross-national perspective (New Haven: Yale University Press, 1984-1987).

110. Agate Nesaule, Woman in amber: Healing the trauma of war and exile (New York: Soho,1995): 9 . 
Herman, adds: "To speak about [violent] experiences in sexual or domestic life was to invite public humiliation, ridicule and disbelief." 111

An interpretation that emphasizes the interplay of male intolerance and female reluctance would not be without historical precedent. Working on a similar set of circumstances in postwar Soviet-occupied East Germany, psychologist Erika Hoerning has argued that while German women who had suffered rape at the hands of Soviet soldiers in 1945 were by and large loyal to their men, and did not blame them for the violence they had suffered, the men were in denial and often accused their abused and terrorized women of fraternizing with the enemy, a contemporary equivalent of victimizing the victim of rape twice: terrorized by Soviet forces, the rape victim was in turn ostracized by her family and community. ${ }^{112}$ The woman's implied "consent" to be a victim of violence (exemplified by the fact that she lived to tell the tale rather than dying in the struggle to save her virtue) meant ipso facto that she had collaborated with her perpetrator, and deserved not compassion but disdain.

In all of the above scenarios, there are ample combinations for reaching a satisfactory, though tragic, explanation for the relative silence on women's contributions, and gender violence, in the Ukrainian insurrection. Ukrainian women certainly provided substantial contributions to the Ukrainian struggle, and there is little excuse or explanation for the subsequent silence about it.

\section{The dynamics of Soviet policing}

But is it fair to focus on the victims alone to explain the apparent divergency between Soviet and Ukrainian accounts? Mass terror, mass arrests, imprisonment, torture, rape, were all tactics that fell under the rubric of Soviet dezorganizatsiia "disorganization" of the enemy's home base. Soviet state violence was a means, not

111. Judith Herman, Trauma and recovery: The aftermath of violence - from domestic abuse to political terror (New York: Basic Books, 1992, 1997): 4; Katherine R. Jolluck, "Gender, identity and the Polish experience of war, 1939-1945" (Ph.D. Diss., Stanford University, 1995): $160-161$.

112. Erika M. Hoerning, “The myth of female loyalty,” Journal of Psychohistory, 16, 1 (1988): 19-46. Cf. Elizabeth Heineman, "The hour of the woman: Memories of Germany's "crisis years' and West German national identity," American Historical Review, 101, 2 (April 1996): 354-395. On Soviet rape in East Germany, see Norman Naimark, The Russians in Germany: A history of the Soviet Zone of occupation, 1945-1949 (Cambridge: Belknap Press of Harvard University Press, 1995): 69-140. Cf. Meinhard Stark, "Ich muß sagen wie es war" Deutsche Frauen des GULag (Berlin: Metropol-Verlag, 1998).

After forty-five years of silence, noted Hungarian child psychologist from Transylvania, Alaine Polcz, revealed in her memoirs first published in 1991 that she had been gang-raped hundreds of times by Soviet soldiers in 1945. In Polcz's account, Soviet soldiers reserved especially brutal reprisals for women suspected of pro-German collaboration: "The Russians, after first raping them, cut off with knives the breasts of the women who had cohabited with the Germans." This usually followed ritualized scenes of humiliation where the women's heads were shaved, and then they were marched down local streets humiliated by jeers and insults from their former neighbors. A. Polcz, A wartime memoir: Hungary, 1944-1945 (Budapest: Corvina, 1991-1998): 65. 
an end: it was neither the product of excesses of individuals, nor an end in itself, but was part of a deliberate campaign to destroy the self-identity of local populations, to drive a wedge between organized resistance and the society-at-large, and to intimidate further potential acts of opposition. Two accounts, taken verbatim from a Soviet Communist Party Control Commission review in 1946 of the first eighteen months of the Ukrainian Communist Party's struggle against nationalist rebels in West Ukraine after the war, reveal the degree to which Soviet MVD/MGB officers in West Ukraine exploited rape for their own personal and operational interests:

"Chief of the Gliniavskyi raion MVD in L'viv oblast' Matiukhin P. E. in February [1946], while interrogating [ethnic Ukrainian woman] Mikhal'skaia E. G., raped and brutally beat her. Kept under arrest from 27 January to 18 February of this year, Mikhal'skaia has been released from prison [following a determination that she had been arrested on the basis] of unsubstantiated charges. Matiukhin likewise raped at least four other illegally arrested girls: Pasternak, Kostyv, Pokyra and Stepanova. [In each case], they were released after having been subjected to violence and insults."113

"Chief of the Bogorodchanskyi raion MVD in Stanyslaviv oblast' Bespalov M.D. and his deputy Borisov I.Z. in February of this year illegally arrested women citizens Snyt 'ko Mariia and Fanega Praskov'ia. Both were beaten during interrogation and then incarcerated in a cold cell. After her release Snyt'ko died from wounds suffered during the beating. Snit'ko's corpse lay in her apartment for two days until it was discovered by neighboring peasants who threatened retaliation against those who had done this to her in the raion MVD headquarters."114

Rape was an integral part of Soviet interrogation methods of West Ukrainian women. In his diaries, Polish doctor Zygmunt Klukowski recalled: "In our cell we could sometimes hear the shouts and loud crying of those questioned [...], particularly women." 115 The precise nature of what went on there was suggested by the powerful words of Polish inmate Eugenia Swojda: "[A]s a woman I was driven to despair."116 A Latvian woman who survived six months of Soviet incarceration and interrogation back in the 1940s, and then remained silent about her ordeal for the next fifty years, recalled:

"I was questioned in all sorts of ways, beaten in all sorts of ways, they did everything. They took me where nails are pulled off, where people were

113. Top secret report of N. Gusarov, Inspector TsK VKP(b), to secretaries of the Central Committee of the USSR, Stalin, Zhdanov, Kuznetsov, Patolichev, and Popov, "Nedostatki i oshibki v ideologicheskoi rabote KP(b)U[krainy]," 13 August 1946. RGASPI, f. 17, op. 122, d. $137,1.44$.

114. Ibid., 11. 44-45.

115. Z. Klukowski, op. cit.: 148; Cf. the account in Jan Tomasz Gross, Revolution from abroad: The Soviet conquest of Poland's western Ukraine and western Belorussia (Princeton: Princeton University Press, 1988): 181.

116. From an account in 1940. K. R. Jolluck, op. cit.: 142. On Soviet interrogation of Polish women, see Ibid:: 87-190. 
writhing on electrical chairs. They said, 'you will get the same if you don't tell us where your brothers and the others are.' Dear lord! What can I say?’117

In the face of organized Soviet mass terror, local populations were dumbstruck, silenced, cowed into submission, often remaining silent for decades after the violence had ended. And perhaps this was, after all, the whole point of the Soviet brutality: to disorganize the local population, to deprive them of any hope of effective resistance to Soviet power.

There are no better illustrations of the Soviet use of rape as a tactical weapon in warfare than those found in the records of Soviet spetsgruppy in West Ukraine: evidently, special MGB maskirovka units regularly brutalized local Ukrainian women while disguised as rebels. Here is just one of myriad examples found in Soviet police files:

"On the night of 23 July 1948 the same spetsgruppa [masquerading as rebel bandits] from Podvysots'ke village abducted in the forest a young woman REPNYTSKA Nina Iakovlevna, born in 1931.

In the forest REPNYTSKA was subjected to tortures.

While interrogating REPNYTSKA, members of the spetsgruppa beat her severely, hung her upside down by her legs, forced a stick into her genitalia, and then one by one raped her.

In a helpless condition, REPNYTSKA was abandoned in the forest, where her husband found her and took her to the hospital, where REPNYTSKA spent an extended period recovering." 118

The logic? Following officially sanctioned procedures, Soviet policemen disguised themselves as rebels, then perpetrated atrocities in their name, hoping in this way to provoke distrust and antagonism between rebel units and the local population. In this context, gender violence was not an end in itself, but a tactical weapon that utilized women's bodies to fight a wider conflict.

Whether they were rapists in Soviet uniforms, petty officials in the local apparatus, or even members of Soviet spetsgruppy perpetrating acts of gender violence under orders, Soviet authorities did themselves play a critical role in the creation of an image of the enemy other that included not just Ukrainian men, but also Ukrainian women and children. The logic of Soviet institution building dictated a definition of the Ukrainian enemy that would justify violence against young and old, male and female. At a meeting of thirty-five Soviet Party, MGB, and MVD officers in West Ukraine with then General Secretary Lazar' Kaganovich, Nikita Khrushchev, and Ukrainian Minister of State Security S. R. Savchenko in L'viv on 23 April 1947, the Drohobych obkom secretary Gorobets noted that $60 \%$ of all locals sentenced for Ukrainian nationalism in 1946

117. From an interview in the 1990s by medical anthropologist Vieda Skultans, as cited in The testimony of lives: Narrative and memory in post-Soviet Latvia (New York and London: Routledge, 1998): 137.

118. TsDAHO, f. 1, op. 16, d. 68,11. 10-17. For the text of the report and discussion of broader operational considerations, see J. Burds, “Agentura,” art. cit.: 129-130. 
had been women and girls, even as only $8 \%$ of the local UPA rank-and-file were female. ${ }^{119}$ Stanyslaviv obkom secretary M. Slon' explained the reasoning for the disproportionate focus on Ukrainian women and children: "We must repress family members as traitors against the nation. We must deport families of rebels as dangerous threats to state security." 120 The logic of the mass arrests and mass deportations was to punish not just the rebels, but also their families, friends, and loved ones, all who fell into Soviet punitive traps as "collaborators" with the organized anti-Soviet opposition. Add to this the practical issue: while male rebels often managed to elude Soviet capture, their wives, mothers, daughters, cousins, and neighbors were readily available for retaliation delivered at the hands of frustrated Stalinist policemen.

The corollary of this argument would be that if the Ukrainian rebel woman had not existed, the Soviet state would certainly have created her. For we are speaking here not just about individual acts of violence, but of a deepseated and powerfully institutionalized state violence in which Soviet cadres had to be rallied time and again to transform abstract justice into particular acts of "enforcement." Which is to say: Ukrainian women appear so often as enemy rebels in Soviet profiles not just because there really were so many women rebels, but also because there were so many women victims of Soviet power. Here, as so often, the crime contained the seeds for its own self-justification and legitimization: from the Soviet police perspective, Ukrainian women were punished because they were rebels. Which is just another way of saying: if their victims were guilty, then the police were selfassuredly innocent of any crime when they perpetrated acts of terror against them. In the same way that well-dressed women were once blamed for luring their own rapists, Ukrainian women were - by Soviet definition - deserving of any punishment they received at the hands of Soviet policemen. For Soviet power in West Ukraine, the law could be adapted to legitimize any act of state-sponsored terror.

\author{
Department of History \\ Northeastern University \\ 249 Meserve Hall \\ Boston, MA 02115 \\ e-mail :jburds@ziplink.net
}

119. "Protokol o soveshchanii sekretarei obkomov i nachal'nikov oblupravlenii MGB zapadnykh oblastei USSR,” RGASPI, f. 81, op. 3, d. 128,11. 150-171 (1. 155).

120. Ibid., 1. 153. 